\title{
Ten-year return levels of sub-daily extreme precipitation over Europe
}

\author{
Benjamin Poschlod ${ }^{1}$, Ralf Ludwig ${ }^{1}$, and Jana Sillmann ${ }^{2}$ \\ ${ }^{1}$ Department of Geography, Ludwig-Maximilians-Universität München, 80333 Munich, Germany \\ ${ }^{2}$ Center for International Climate and Environmental Research (CICERO), Oslo, 0318, Norway \\ Correspondence: Benjamin Poschlod (Benjamin.Poschlod@1mu.de)
}

Received: 8 June 2020 - Discussion started: 4 August 2020

Revised: 26 January 2021 - Accepted: 8 February 2021 - Published: 11 March 2021

\begin{abstract}
Information on the frequency and intensity of extreme precipitation is required by public authorities, civil security departments, and engineers for the design of buildings and the dimensioning of water management and drainage schemes. Especially for sub-daily resolutions, at which many extreme precipitation events occur, the observational data are sparse in space and time, distributed heterogeneously over Europe, and often not publicly available. We therefore consider it necessary to provide an impact-orientated data set of 10-year rainfall return levels over Europe based on climate model simulations and evaluate its quality. Hence, to standardize procedures and provide comparable results, we apply a high-resolution single-model large ensemble (SMILE) of the Canadian Regional Climate Model version 5 (CRCM5) with 50 members in order to assess the frequency of heavy-precipitation events over Europe between 1980 and 2009. The application of a SMILE enables a robust estimation of extreme-rainfall return levels with the 50 members of 30 -year climate simulations providing 1500 years of rainfall data. As the 50 members only differ due to the internal variability in the climate system, the impact of internal variability on the return level values can be quantified.

We present 10-year rainfall return levels of hourly to $24 \mathrm{~h}$ durations with a spatial resolution of $0.11^{\circ}(12.5 \mathrm{~km})$, which are compared to a large data set of observation-based rainfall return levels of 16 European countries. This observation-based data set was newly compiled and homogenized for this study from 32 different sources. The rainfall return levels of the CRCM5 are able to reproduce the general spatial pattern of extreme precipitation for all sub-daily durations with Spearman's rank correlation coefficients $>0.76$ for the area covered by observations. Also, the rainfall intensity of the observational data set is in the range of the climate-model-generated intensities in $60 \%(77 \%, 78 \%, 83 \%, 78 \%)$ of the area for hourly $(3,6,12,24 \mathrm{~h})$ durations. This results in biases between $-16.3 \%$ (hourly) to $+8.2 \%(24 \mathrm{~h}$ ) averaged over the study area. The range, which is introduced by the application of 50 members, shows a spread of $-15 \%$ to $+18 \%$ around the median.

We conclude that our data set shows good agreement with the observations for 3 to $24 \mathrm{~h}$ durations in large parts of the study area. However, for an hourly duration and topographically complex regions such as the Alps and Norway, we argue that higher-resolution climate model simulations are needed to improve the results. The 10-year return level data are publicly available (Poschlod, 2020; https://doi.org/10.5281/zenodo.3878887).
\end{abstract}




\section{Introduction}

Sub-daily precipitation extremes affect our daily lives with a wide range of consequences that can have impacts on infrastructure, economy, and even health. Short-duration events of minutes and up to several hours can cause urban flooding, trigger landslides, flash floods, and snow avalanches or induce heavy erosion (Arnbjerg-Nielsen et al., 2013; Bruni et al., 2015; Gill and Malamud, 2014; Marchi et al., 2010; Ochoa-Rodriguez et al., 2015; Panagos et al., 2017). Heavyrainfall events of several hours and up to days can lead to river flooding or coastal flooding as a singular trigger or as a contributing process of compound flooding events such as rain-on-snow or coastal compound floods due to joint river runoff and storm surge (Bevacqua et al., 2017, 2019; Cohen et al., 2015; van den Hurk et al., 2015; Poschlod et al., 2020). These hazards have large impacts on the European infrastructure of urban drainage systems, roads and railroads, waterway transport, electricity, and communication networks (Forzieri et al., 2018; Groenemeijer et al., 2015; Nissen and Ulbrich, 2017). The agricultural sector is directly affected by flooded crop fields and therefore lost yields and in the longer term by eroding soils and leaching nutrients (Mäkinen et al., 2018; Panagos et al., 2017). Due to increased settlement in flood-prone areas, the financial impact on the economic, societal, and private sector has risen in Europe over the past decades (Barredo, 2009; Forzieri et al., 2018; Rojas et al., 2013). Human health is also affected, as these hazards can cause accidents or even fatalities (Krøgli et al., 2018; Petrucci et al., 2019). The Munich Re NatCatSERVICE reports financial losses of around EUR 173 billion for the 33 member states of the European Environment Agency between 1980 and 2017 due to floods and mass movements (EEA, 2019). Over 4600 people have lost their lives because of these hazards.

Hence, we conclude that the frequency and intensity of heavy-precipitation events as triggers of high-impact floods, mass movements, and erosion is of great financial and societal relevance. In this study, we analyse precipitation dynamics at the sub-daily timescale. For these durations, the observational network for precipitation over Europe is distributed quite heterogeneously. The density of observations is sparse, and the time periods of observed data are often too short to assess extreme events (Lewis et al., 2019a). The data availability is limited and the "data processing stage" varies for each country or even region. The provided rainfall products cover the range of in situ annual maxima of sub-daily precipitation, in situ time series of sub-daily precipitation, in situ return levels, areal time series, and areal return levels. It depends on the respective meteorological office if the data are available via open access or only by registration and in which format the data are provided. Additionally, access to the data is often complicated by the fact that the relevant information, often provided on websites or data sheets, is only available in the national language. These difficulties may be partly solved by the Global Sub-Daily Rainfall Dataset (GSDR; Lewis et al., 2019a), which was not yet accessible during the conduct of this study. However, the GSDR provides in situ data covering limited time periods and participating countries only.

Therefore, we see a need to generate a homogeneous data set of rainfall return levels over Europe based on climate model simulations and to evaluate its quality. We choose 10 -year return periods of hourly and $3,6,12$, and $24 \mathrm{~h} \mathrm{du}-$ rations. The limited time period of observational data suggests that a relatively moderate return period should be chosen to ensure comparability with observations. Additionally, the 10-year return level as a threshold for the detection of extreme events has already been chosen by Nissen and Ulbrich (2017) based on legislation and stakeholder interviews. Also, the recent study of Berg et al. (2019) calculates this return level for nine selected regional climate models of the EURO-CORDEX multimodel ensemble.

The durations between $1 \mathrm{~h}$ and $24 \mathrm{~h}$ cover a variety of rainfall-generating mechanisms such as convection, advection, and orographic precipitation. The complexity of these processes inducing extreme precipitation, their inherent intermittency properties, and their variability are still not well understood and a matter for recent climate and weather research (Trenberth et al., 2017; Das et al., 2020). Hence, the comparison to observational data is also relevant for the evaluation of the process knowledge within the regional climate model and the applied parametrization schemes.

\section{Data and methods}

\subsection{The Canadian Regional Climate Model version 5 Large Ensemble (CRCM5-LE)}

The global climate for this study is based on a large ensemble of global climate model (GCM) simulations, which was performed with the Canadian Earth System Model version 2 (CanESM2) at the rather broad spatial resolution of $2.8^{\circ}$ (Arora et al., 2011; Fyfe et al., 2017). The CanESM2 was run for 1000 years forced by constant preindustrial conditions. After applying small random atmospheric perturbations, five runs with differing initial conditions were set up starting in January 1850 (Leduc et al., 2019). On 1 January 1950, 10 new random atmospheric perturbations were applied to each of the five runs resulting in an ensemble of 50 members in sum. These 50 simulations were forced with estimations of historical $\mathrm{CO}_{2}$ and non- $\mathrm{CO}_{2}$ greenhouse gas emissions, aerosol concentrations, and land use until December 2005 (Arora et al., 2011). From 2006 to 2099, the climate projections follow the radiative forcing from the representative concentration pathway (RCP) 8.5.

Implementing slight atmospheric perturbations in 1850 and 1950 results in different climate realizations, though neither the atmospheric forcing nor the model dynamics, physics, or structure was changed (Arora et al., 2011). The climate projections only differ due to the internal variability 
in the climate system, which is caused by non-linear dynamical processes intrinsic to the atmosphere (Deser et al., 2012; Hawkins and Sutton, 2009; von Trentini et al., 2019).

The framework for the design of the single-model large ensemble (SMILE) of the regional climate model (RCM) as well as the simulations of the CRCM5-LE were then carried out within the ClimEx project (Climate Change and Hydrological Extreme Events - Risks and Perspectives for Water Management in Bavaria and Québec). Each of the 50 CanESM2 simulations were dynamically downscaled with the CRCM5 applying the EURO-CORDEX grid specifications $\left(0.11^{\circ}\right.$ horizontal resolution equalling around $\left.12.5 \mathrm{~km}\right)$.

The precipitation-related physical parametrization schemes in the CRCM5 setup include the following modules (Bresson et al., 2017; Martynov et al., 2012, 2013): subgrid-scale orographic gravity-wave drag by McFarlane (1987) is implemented, and low-level orographic blocking is parametrized via Zadra et al. (2003). The planetary boundary layer scheme (Benoit et al., 1989; Delage, 1997; Delage and Girard, 1992) was used in a modified version by McTaggartCowan and Zadra (2015) in order to introduce hysteresis effects. The Sundquist (Sundquist, 1978; Sundquist et al., 1989) scheme is applied as a condensation scheme to diagnose large-scale precipitation. Shallow convection is parametrized with the Kuo transient scheme (Bélair et al., 2005; Kuo, 1965), and deep convection is described with the Kain and Fritsch (1990) scheme. Land surface processes are simulated by the Canadian Land Surface Scheme, version 3.5 (CLASS3.5; Verseghy, 1991, 2009), and lakes are modelled with the one-dimensional freshwater lake model (FLake; Martynov et al., 2012, 2013). For the details of the whole CRCM5 setup the reader may refer to Martynov et al. (2012) or Hernández-Díaz et al. (2012).

RCM SMILEs are relatively rare due to the high demands on computing power. In addition to the CRCM5-LE only the 21-member CESM-COSMO-CLM SMILE with a horizontal spatial resolution of $0.44^{\circ}$ (Addor and Fischer, 2015) and the 16-member EC-EARTH-RACMO2 SMILE with a horizontal spatial resolution of $0.11^{\circ}$ (Aalbers et al., 2018) are available for a European domain. Although newer model versions are already available, such as CanESM5 (Swart et al., 2019), the existing CRCM5-LE provides a unique database with the highest number of members, largest domain, and highest spatial resolution available.

In this study, we focus on the precipitation during the time period of 1980 to 2009, which is simulated by the CRCM5 and stored in an hourly resolution. Hence, for the calculation of return periods, 1500 years of hourly precipitation under conditions of this climate period are available. Leduc et al. (2019) evaluate mean precipitation during 1980 to 2012 by comparing the annual rainfall with E-OBS data over the whole European domain. Generally, the CRCM5-LE shows a wet bias in mean precipitation of up to $2 \mathrm{mmd}^{-1}$ during the winter and less than $1 \mathrm{mmd}^{-1}$ for the summer, spring, and fall periods. Regions with higher biases are located at the west coasts of Spain, Portugal, Ireland, the UK, Norway, Croatia, Albania, and Greece and in the topographically complex areas of the Alps, Carpathians, and Pyrenees (Leduc et al., 2019). These precipitation biases are in the range of the EURO-CORDEX models as well (Kotlarski et al., 2014).

\subsection{Calculation of rainfall return periods}

In climate science, extreme precipitation is mostly assessed via the analysis of high quantiles, such as the $99.7 \%$ quantile, which equals the occurrence probability of an event happening once per year (Santos et al., 2016; Hennemuth et al., 2013). Risk analysis, engineering guidelines, and also legislative thresholds are often expressed as return levels. Applying extreme value theory (EVT), return periods can be calculated by fitting extreme value distributions to a selection of independent and identically distributed samples of extreme events (Coles, 2001). EVT consists of the two fundamentally different sampling strategies block maxima (BM) and peak over threshold (POT). By choosing annual block maxima as a sampling strategy, we ensure that the extreme samples are independent from each other. Still, sampling only one event per year may result in a loss of information compared to the POT approach. Also, lower-intensity observations, which are not extreme but still the maximum value of the year, may be included due to the application of the BM strategy.

Due to the hourly resolution of the CRCM5-LE data, the hourly maxima are constrained to the fixed window at the full hour (e.g. 06:00 to 07:00). For all other durations $(3,6,12$, and $24 \mathrm{~h}$, respectively) we allow hourly moving windows for the selection of maxima.

We applied a Mann-Kendall test with $p=0.05(0.01)$ on the 50 series of 30 annual maxima and five different durations revealing a trend for less than $6 \%(1 \%)$ of all grid cells over all durations. The affected grid cells vary in location within the 50 climate model simulations, and we therefore do not apply any de-trending methods.

Following the Fisher-Tippett theorem, the distribution of block maxima samples converges to the generalized extreme value (GEV) distribution Eq. (1):

$$
G(x ; \xi)= \begin{cases}\exp \left(-\left[1+\xi\left(\frac{x-\mu}{\sigma}\right)\right]^{-1 / \xi}\right), & \xi \neq 0 \\ \exp \left(-\exp \left(-\frac{x-\mu}{\sigma}\right)\right), & \xi=0\end{cases}
$$

where $\mu, \sigma$, and $\xi$ represent the location, scale, and shape parameters of the distribution. The shape parameter $\xi$ governs the tail behaviour of the GEV distribution. According to the value of $\xi$, the GEV corresponds to the Gumbel ( $\xi=$ $0)$, Fréchet $(\xi>0)$, or Weibull $(\xi<0)$ distribution (Coles, 2001). We fit the location, scale, and shape parameters separately for each of the 50 differing 30-year block maxima via the method of L-moments (Hosking et al., 1985) using the software package by Gilleland and Katz (2016). The method of L-moments has proven to deliver stable results for 
small sample sizes (Delicado and Goria, 2008; Hosking et al., 1985; Kharin and Zwiers, 2000). We have also applied maximum likelihood estimation (MLE). There, the median return levels are almost equal to L-moments, but the variability within the 50 members is slightly larger due to more unstable results at the edges of the ensemble. MLE is recommended by Delicado and Goria (2008) for sample sizes of $n \geq 50$, which is why we keep the fits based on the method of L-moments. The goodness of fit is assessed applying the Anderson-Darling test with a $5 \%$ significance level following Chen and Balakrishnan (1995). The goodness-of-fit test with a $5 \%$ significance level at $280 \times 280$ grid cells for 50 members would yield 196000 locations on average, where the null hypothesis is erroneously rejected, also called the type I error or false positives (Ventura et al., 2004). Hence, we apply the false discovery rate (FDR) (Benjamini and Hochberg, 1995) following the approach of Wilks (2016), which adjusts the critical $p$ value for statistical testing at many locations. Less than $0.1 \%$ of all fits are rejected for all durations. The median values of $\mu, \sigma$, and $\xi$, as well as the respective standard deviation over the 50 members, are shown within the Supplementary materials. The 10-year return periods are calculated inverting Eq. (1). For the most robust estimation at each grid cell, the median of the 50 return periods is chosen.

\section{Observational rainfall return periods}

The observational data are combined from many different national precipitation data sets. This special effort had to be made, since reanalysis products underrepresent extreme events due to the interpolation methods, especially in regions with a low measuring network density and for short-duration events at local scales (Hofstra et al., 2008). In order to compare the national observational data to the climate model output, areal precipitation data sets of observations are linearly rescaled to the $0.11^{\circ} \mathrm{CRCM} 5$ grid. Point observations are spatially interpolated via ordinary kriging and aggregated to the $0.11^{\circ}$ grid of the CRCM5-LE. We describe the data processing for each national data set in the following. Table 1 provides an overview of the applied observational data and how they were accessed.

\subsection{National data}

\subsubsection{Germany}

The German weather service provides an estimation of rainfall return periods based on 5 min resolution gauge observations between 1951 and 2010 (DWD, 2019; publicly available). The documentation of the data processing is given in Malitz and Ertel (2015). A POT approach was chosen to sample extreme events. Events between May and September were de-clustered to guarantee independent samples. After fitting an exponential distribution, the calculated return peri- ods are spatially interpolated over Germany resulting in grid cells of approximately $8 \mathrm{~km}$. We rescale these grids linearly to the $0.11^{\circ}$ specifications of the CRCM5-LE.

\subsubsection{Austria}

The Austrian data set is publicly available for single grid cells on a web portal by the Federal Ministry of Agriculture, Regions and Tourism (BMLRT, 2019). For the generation of the return periods, the rain gauge data are supplemented by a convective weather model in order to improve the density of observations (Kainz et al., 2007). Similarly to the German dataset, a POT approach was applied. Details are reported in BMLRT (2006). We linearly interpolate the Austrian data to the $0.11^{\circ}$ grid.

\subsubsection{Belgium}

Return periods of extreme precipitation in Belgium were calculated by van de Vyver (2012). Therefore, a spatial GEV model was applied considering multisite data. The GEV parameters are related to geographical and climatological covariates through a regression relationship. The data are provided by the Belgian Royal Meteorological Institute (RMI, 2019; publicly available) for each commune. We interpolate the communal point data on the CRCM5-LE grid via ordinary kriging.

\subsubsection{France}

Embedded in the framework of SHYPRE (Simulated Hydrographs for flood Probability Estimation; Arnaud and Lavabre, 2002), Arnaud et al. (2008) apply an hourly stochastic rainfall model to derive return periods of extreme precipitation in France. The data are not publicly available and were already provided with the CRCM5-LE grid specifications by Patrick Arnaud with permission of Météo-France.

\subsubsection{Switzerland}

In Switzerland, return periods of hourly and 3, 6, and $12 \mathrm{~h}$ precipitation are available at 67 rain gauges for the time period 1981 to 2019 (MeteoSwiss, 2016). They were calculated by fitting a GEV to seasonal maxima via Bayesian estimation. As $24 \mathrm{~h}$ return periods are not provided, we use the estimates for daily extreme precipitation, which cover a time period from 1966 to 2015 at 337 sites. We apply an adjustment factor of 1.14 to transfer the daily fixed-window return levels to $24 \mathrm{~h}$ moving-window levels as this relation has been found to be rather stable (Barbero et al., 2019; Boughton and Jakob, 2008). Within the CRCM5-LE, we find a factor of 1.13 between daily and $24 \mathrm{~h}$ return periods, which confirms this relationship. We interpolate the pointwise estimations of the return levels to the CRCM5 grid applying ordinary kriging. 
Table 1. Overview of the national observational precipitation data sets in the same order as in Sect. 3.1.

\begin{tabular}{|c|c|c|c|}
\hline Country or state & Source & DOI, URL, or ISBN & Access \\
\hline Germany & DWD & $\begin{array}{l}\text { https://opendata.dwd.de/climate_environment/CDC/ } \\
\text { grids_germany/return_periods/precipitation/KOSTRA/ } \\
\text { KOSTRA_DWD_2010R/asc/ }\end{array}$ & $\begin{array}{l}\text { Open access; last ac- } \\
\text { cess: } 21 \text { October } 2019\end{array}$ \\
\hline Austria & BMLRT & https://ehyd.gv.at/ & $\begin{array}{l}\text { Open access; last ac- } \\
\text { cess: } 22 \text { October } 2019\end{array}$ \\
\hline Belgium & RMI & $\begin{array}{l}\text { https://www.meteo.be/fr/climat/atlas-climatique/ } \\
\text { climat-dans-votre-commune }\end{array}$ & $\begin{array}{l}\text { Open access; last ac- } \\
\text { cess: } 1 \text { October } 2019\end{array}$ \\
\hline France & $\begin{array}{l}\text { Patrick Arnaud, } \\
\text { Météo-France }\end{array}$ & - & $\begin{array}{l}\text { No open access; } \\
\text { data were provided } \\
\text { by Patrick Arnaud } \\
\text { with permission of } \\
\text { Météo-France }\end{array}$ \\
\hline Switzerland & MeteoSwiss & $\begin{array}{l}\text { https://www.meteoswiss.admin.ch/home/climate/ } \\
\text { swiss-climate-in-detail/extreme-value-analyses/ } \\
\text { standard-period.html?station=int }\end{array}$ & $\begin{array}{l}\text { Open access; last ac- } \\
\text { cess: } 11 \text { October } 2019\end{array}$ \\
\hline Norway (1-12 h) & $\begin{array}{l}\text { Dyrrdal et al. } \\
(2015), \text { NMI }\end{array}$ & 皮 & $\begin{array}{l}\text { No open access; data } \\
\text { were provided by NMI } \\
\text { for research only }\end{array}$ \\
\hline Norway (24 h) & $\begin{array}{l}\text { Lussana and Tveito } \\
\text { (2017) }\end{array}$ & https://doi.org/10.5281/zenodo.845733 & $\begin{array}{l}\text { Open access; last ac- } \\
\text { cess: } 11 \text { January } 2020\end{array}$ \\
\hline Slovenia & SEA & $\begin{array}{l}\text { http://meteo.arso.gov.si/met/sl/climate/tables/precip_ } \\
\text { return_periods_newer/ }\end{array}$ & $\begin{array}{l}\text { Open access; last ac- } \\
\text { cess: } 30 \text { January } 2020\end{array}$ \\
\hline United Kingdom & $\begin{array}{l}\text { Lewis et al. } \\
\text { (2019b) }\end{array}$ & $\begin{array}{l}\text { https://doi.org/10.5285/d4ddc781-25f3-423a-bba0- } \\
\text { 747cc82dc6fa }\end{array}$ & $\begin{array}{l}\text { Open access; last ac- } \\
\text { cess: } 23 \text { January } 2020\end{array}$ \\
\hline Denmark & $\begin{array}{l}\text { Madsen et al. } \\
(2017)\end{array}$ & - & $\begin{array}{l}\text { Single numbers for the } \\
\text { whole country are given } \\
\text { in Sect. } 3.1 .9\end{array}$ \\
\hline The Netherlands (1-12 h) & $\begin{array}{l}\text { Beersma et al. } \\
(2018)\end{array}$ & - & $\begin{array}{l}\text { Single numbers for the } \\
\text { whole country are given } \\
\text { in Sect. } 3.1 .10\end{array}$ \\
\hline The Netherlands $(24 \mathrm{~h})$ & KNMI & $\begin{array}{l}\text { https://data.knmi.nl/datasets/Rd1/5\&Openaccess; last } \\
\text { access: } 2 \text { October } 2019\end{array}$ & \\
\hline Sweden & $\begin{array}{l}\text { Olsson et al. } \\
(2018)\end{array}$ & $\begin{array}{l}\text { https://www.smhi.se/polopoly_fs/1.134304!/ } \\
\text { klimatologi_47_4.pdf }\end{array}$ & $\begin{array}{l}\text { Open access; last ac- } \\
\text { cess: } 30 \text { July } 2020\end{array}$ \\
\hline Finland ( $1 \mathrm{~h})$ & $\begin{array}{l}\text { Aaltonen et al. } \\
(2008)\end{array}$ & $\begin{array}{l}\text { https://helda.helsinki.fi/bitstream/handle/10138/38381/ } \\
\text { SY_31_2008.pdf }\end{array}$ & $\begin{array}{l}\text { Open access; last ac- } \\
\text { cess: } 30 \text { July } 2020\end{array}$ \\
\hline Finland (6 and $24 \mathrm{~h})$ & $\begin{array}{l}\text { Venäläinen et al. } \\
\text { (2007) }\end{array}$ & $\begin{array}{l}\text { https://helda.helsinki.fi/bitstream/handle/10138/1138/ } \\
\text { Korjattu2007nro\{\%\}204.pdf }\end{array}$ & $\begin{array}{l}\text { Open access; last ac- } \\
\text { cess: } 30 \text { July } 2020\end{array}$ \\
\hline \multicolumn{4}{|c|}{$\mathrm{J}$} \\
\hline Basilicata & $\begin{array}{l}\text { Manfreda et al. } \\
(2015)\end{array}$ & $\begin{array}{l}\text { http://www.centrofunzionalebasilicata.it/it/pdf/ } \\
\text { pioggia_download.pdf }\end{array}$ & $\begin{array}{l}\text { Open access; last ac- } \\
\text { cess: } 30 \text { July } 2020\end{array}$ \\
\hline Calabria & ARPACAL & $\begin{array}{l}\text { http://www.cfd.calabria.it/index.php/dati-stazioni/ } \\
\text { dati-storici }\end{array}$ & $\begin{array}{l}\text { Open access; personal } \\
\text { registration needed; } \\
\text { last access: } 30 \text { January } \\
2020\end{array}$ \\
\hline Friuli Venezia Giulia & ARPAFVG & https://www.osmer.fvg.it/clima.php?ln= & $\begin{array}{l}\text { Open access; last ac- } \\
\text { cess: } 10 \text { January } 2020\end{array}$ \\
\hline Marche & PCRM & $\begin{array}{l}\text { http://app.protezionecivile.marche.it/sol/indexjs.sol? } \\
\text { lang=en\&Ok=1 }\end{array}$ & $\begin{array}{l}\text { Open access; user ac- } \\
\text { count necessary; last } \\
\text { access: } 20 \text { December } \\
2019\end{array}$ \\
\hline Piedmont & ARPAP & $\begin{array}{l}\text { https://www.arpa.piemonte.it/rischinaturali/ } \\
\text { accesso-ai-dati/annali_meteoidrologici/ } \\
\text { annali-meteo-idro/banca-dati-meteorologica.html }\end{array}$ & $\begin{array}{l}\text { Open access; Java ap- } \\
\text { plication; last access: } \\
20 \text { January } 2020\end{array}$ \\
\hline
\end{tabular}


Table 1. Continued.

\begin{tabular}{|c|c|c|c|}
\hline Country or state & Source & DOI, URL or ISBN & Access \\
\hline Tuscany & RT & http://www.sir.toscana.it/consistenza-rete & $\begin{array}{l}\text { Open access; last } \\
\text { access: } 11 \text { December } \\
2019\end{array}$ \\
\hline Trento & Meteotrentino & http://storico.meteotrentino.it/web.htm & $\begin{array}{l}\text { Open access; last } \\
\text { access: } 21 \text { December } \\
2019\end{array}$ \\
\hline Umbria & $\begin{array}{l}\text { Morbidelli et al. } \\
\text { (2016) }\end{array}$ & ISBN (EAN): 978-88-6074-805-8 & - \\
\hline Aosta Valley & CFRAVA & https://cf.regione.vda.it/portale_dati.php & $\begin{array}{l}\text { Open access; last ac- } \\
\text { cess: } 5 \text { January } 2020\end{array}$ \\
\hline Lazio & CFRRL & $\begin{array}{l}\text { http://www.idrografico.regione.lazio.it/std_page. } \\
\text { aspx-Page=curve_pp.htm }\end{array}$ & $\begin{array}{l}\text { Open access; last ac- } \\
\text { cess: } 8 \text { January } 2020\end{array}$ \\
\hline Liguria & ARPAL & $\begin{array}{l}\text { https://www.arpal.liguria.it/contenuti_statici/clima/ } \\
\text { atlante/Atlante_climatico_della_Liguria.pdf }\end{array}$ & $\begin{array}{l}\text { Open access; last ac- } \\
\text { cess: } 30 \text { July } 2020\end{array}$ \\
\hline Veneto & ARPAV & https://www.arpa.veneto.it/bollettini/storico/precmax/ & $\begin{array}{l}\text { Open access; last ac- } \\
\text { cess: } 3 \text { January } 2020\end{array}$ \\
\hline Lombardy & $\begin{array}{l}\text { De Michele et al. } \\
\text { (2005) }\end{array}$ & http://idro.arpalombardia.it/manual/lspp.pdf & $\begin{array}{l}\text { Open access; last ac- } \\
\text { cess: } 30 \text { July } 2020\end{array}$ \\
\hline Molise & RM (2001) & http://regione.molise.it/llpp/pdfs/b-1-2.pdf & $\begin{array}{l}\text { Open access; last ac- } \\
\text { cess: } 30 \text { July } 2020\end{array}$ \\
\hline Spain & SMG & $\begin{array}{l}\text { https://meteo.unican.es/tds5/catalog/pr_Spain02_v5.0_ } \\
\text { 011rot/catalog.html?dataset=pr_Spain02_v5.0_011 rot/ } \\
\text { Spain02_v5.0_DD_011rot_aa3d_pr.nc }\end{array}$ & $\begin{array}{l}\text { Open access; last ac- } \\
\text { cess: } 11 \text { November } \\
2019\end{array}$ \\
\hline Portugal & IPMA & $\begin{array}{l}\text { https://www.ipma.pt/en/produtoseservicos/index.jsp? } \\
\text { page=dataset.pt02.xml }\end{array}$ & $\begin{array}{l}\text { Open access; last ac- } \\
\text { cess: } 12 \text { October } 2019\end{array}$ \\
\hline Poland & $\begin{array}{l}\text { Berezwoski et al. } \\
(2015)\end{array}$ & $\begin{array}{l}\text { https://doi.org/10.4121/uuid:e939aec0-bdd1-440f- } \\
\text { bd1e-c49ff10d0a07 }\end{array}$ & $\begin{array}{l}\text { Open access; last ac- } \\
\text { cess: } 21 \text { November } \\
2019\end{array}$ \\
\hline
\end{tabular}

\subsubsection{Norway}

Dyrrdal et al. (2015) generate a spatially coherent map of extreme hourly precipitation return levels in Norway. They link GEV distributions with latent Gaussian fields in a Bayesian hierarchical model to overcome the sparse observational network. The precipitation gauges only operate during an extended summer season, whereas the highest 12 and $24 \mathrm{~h}$ rainfall sums occur during fall and winter in western Norway. Due to this limitation, the data have to be classified as experimental. Hence, for $24 \mathrm{~h}$ return levels, we use the daily gridded precipitation data set seNorge 2 at a $1 \mathrm{~km}$ resolution (Lussana and Tveito, 2017 - publicly available; Lussana et al., 2018), which covers the time period from 1957 to 2019. We fit the GEV to the annual maxima of each $1 \mathrm{~km}$ grid cell and apply the adjustment factor of 1.14 to transfer the daily estimates to moving windows of $24 \mathrm{~h}$. The resulting return levels are then linearly interpolated to the $0.11^{\circ}$ grid.

\subsubsection{Slovenia}

The Slovenian Environment Agency provides rainfall return periods at 63 gauges (SEA, 2020; publicly available), which they derived by fitting a Gumbel distribution (see Eq. 1 with $\xi=0)$. The time periods differ for each site. We interpolate the return levels to the $0.11^{\circ}$ grid via ordinary kriging.

\subsubsection{United Kingdom (without Northern Ireland)}

For the United Kingdom, we use the gridded estimates of hourly areal rainfall for Great Britain (CEH-GEAR1hr; Lewis et al., 2019b; publicly available), which covers a time period of 1990 to 2014 in a $1 \mathrm{~km}$ spatial resolution. For every grid cell and duration, we sample the annual maxima, fit the $\mathrm{GEV}$, and calculate the return levels. Then, we aggregate the areal rainfall return levels to the $0.11^{\circ}$ grid.

\subsubsection{Denmark}

For the Danish climate, the rainfall return levels are assumed to be almost constant with very low variability across the whole country (Madsen et al., 2017). The authors used data of 83 rain gauges with a $1 \mathrm{~min}$ resolution covering the period 1979 to 2012 with more than 10 years of observations. For the extreme value analysis, a partial duration series model is applied to estimate the intensity-duration-frequency relationships of extreme precipitation. We use their average val- 
ues of $24.9 \mathrm{~mm}(33.3,40.2,46.7,55.3 \mathrm{~mm})$ as 10 -year return levels for hourly $(3,6,12,24 \mathrm{~h})$ durations.

\subsubsection{The Netherlands}

As for Denmark, the return levels show very low variability in the Netherlands, which is why the KNMI provides single values for the whole country (Beersma et al., 2018). The 10 -year return levels amount to $31 \mathrm{mmh}^{-1}, 39.8 \mathrm{~mm}(3 \mathrm{~h})^{-1}$, $46.0 \mathrm{~mm}(6 \mathrm{~h})^{-1}$, and $52.9 \mathrm{~mm}(12 \mathrm{~h})^{-1}$. As no estimation for $24 \mathrm{~h}$ return levels is provided, we use daily precipitation sums of the $1 \mathrm{~km}$ resolution gridded data set between 1951 and 2010 (KNMI, 2019; publicly available). The data are based on 300 measurement stations and interpolated via ordinary kriging. After extracting the annual maxima, we fit the GEV and rescale the resulting return level of daily precipitation to the $0.11^{\circ}$ grid. Furthermore, we apply the adjustment factor of 1.14 to transfer the return level to a $24 \mathrm{~h}$ estimate.

\subsubsection{Sweden}

In Sweden, the variability in return periods of extreme precipitation is also assumed to be very low. Olsson et al. (2018) provide tables of hourly and 3,6 , and $12 \mathrm{~h}$ return levels for four regions of Sweden. The estimations are based on over 120 rain gauges covering the period 1996 to 2017. For each of the four regions, all rain gauge data were concatenated into one single time series. A POT approach was carried out, and the generalized Pareto distribution (GPD) was fitted via maximum likelihood estimation. The domain of the CRCM5LE covers only the middle, south-eastern, and south-western Swedish sub-regions. The $24 \mathrm{~h}$ duration is not available, and we therefore apply an extrapolated value for the three regions, which is adapted to the values of the neighbouring countries Finland and Denmark.

\subsubsection{Finland}

Within a project about short-duration rainfall extremes in urban areas, radar measurements over the whole of Finland between 2000 and 2005 have been used to estimate the hourly return level of 10-year rainfall (Aaltonen et al., 2008). The radar measurements of the whole country were pooled to enlarge the database for extreme value analysis. The hourly 10-year return level amounts to $22.9 \mathrm{~mm} \mathrm{~h}^{-1}$ for the whole country. For longer durations of 6 and $24 \mathrm{~h}$, Venäläinen et al. (2007) have calculated return levels for different sites in Finland. As for Denmark, we take one average value for the whole country from the stations, which are covered by the CRCM5-LE domain. For 3 and $12 \mathrm{~h}$ estimates we interpolate according to the values of the neighbouring countries Sweden and Denmark. The final countrywide return levels amount to $22.9 \mathrm{~mm}(27.0,34.0,44.0,53.1 \mathrm{~mm})$ as 10 -year return levels for hourly $(3,6,12,24 \mathrm{~h})$ durations.

\section{1 .13 Italy}

In Italy, meteorological observations are the responsibility of the provincial administration. The data availability, the data format, and the available products differ within all 21 regional authorities. A good overview of this issue is given in Libertino et al. (2018), who also analyse the combined product, Italian Rainfall Extremes Database. However, the authors are not allowed to pass on this database, unless the permission of all individual provincial administrations has been obtained. We therefore focus on data, which are available, and gathered information for 14 provinces. Annual maxima for rain gauges are provided for Basilicata (Manfreda et al., 2015), Calabria (ARPACAL, 2020; personal registration needed), Friuli Venezia Giulia (ARPAFVG, 2020), Marche (PCRM, 2019; user account necessary), Piedmont (ARPAP, 2020; Java application of database has to be downloaded and run), Tuscany (RT, 2019), Trento (Meteotrentino, 2019), Umbria (Morbidelli et al., 2016), and Aosta Valley (CFRAVA, 2020). We fitted the GEV and calculated the 10-year return levels. Rainfall return levels are directly available for stations in Lazio (CFRRL, 2018), Liguria (ARPAL, 2013), and Veneto (ARPAV, 2020). Fitted parameters for the LSPP (linea segnalatrice di probabilità pluviometrica) model are given for rain gauges in Lombardy by de Michele et al. (2005), which can be used to derive rainfall intensities for the 10 -year return period. For the stations in the region of Molise, fitted parameters for an exponential model are provided (RM, 2001). All derived point data of return levels were interpolated applying ordinary kriging.

\subsubsection{Spain}

For Spain, we have only gathered information about daily rainfall return levels. Herrera et al. (2012) have developed a gridded data set of daily precipitation sums based on 2756 measurement stations for the period 1950 to 2003. They used a two-stage kriging approach to interpolate the data. Due to the dense station network, extreme precipitation events are accurately reproduced in contrast to typical reanalysis data sets. The data are publicly available (SMG, 2019). We extracted the annual maxima, fitted the GEV, and applied the adjustment factor of 1.14 to transfer the daily data to $24 \mathrm{~h}$ moving-window estimations. Then we rescaled the gridded data to the specifications of the $0.11^{\circ} \mathrm{CRCM} 5$ grid.

\subsubsection{Portugal}

Following the same approach as the Spanish data set, BeloPereira et al. (2011) have created grid data of daily precipitation. The data set is based on 806 stations, and therefore the dense station network again ensures an accurate reproduction of extremes after the interpolation process. Data are available at IPMA (2019; publicly available). We used the same process as for the Spanish data to estimate $24 \mathrm{~h}$ return levels. 


\subsubsection{Poland}

Berezwoski et al. (2016) applied the interpolation by Herrera et al. (2012) on up to 816 meteorological station data for the time period of 1951 to 2013 . The data are publicly available (Berezwoski et al., 2015). We used the same process as for the Spanish data to estimate $24 \mathrm{~h}$ return levels.

\subsection{Post-processing for the comparison to areal data}

Most of the observational data sets are based on point measurements, whereas the climate model simulates areal estimates of precipitation. In order to improve the comparability of these two kinds of data, areal reduction factors (ARFs) are often applied to the point measurements (Wilson, 1990). ARFs are empirically derived factors and are dependent on the temporal and spatial resolution as well as on the local climate (Sunyer et al., 2016). In addition to the difference in space, we need to apply a correction to the hourly data, as the observations are based on hourly maxima with moving windows, whereas the hourly data of the climate model are constrained to the fixed window between full hours.

To account for different regional climates, we apply differing ARFs. In Finland, Norway, Sweden, Denmark, the United Kingdom, Denmark, the Netherlands, Belgium, Germany, and Switzerland, we apply the ARF from Berg et al. $(2019)$ for $3\left(\mathrm{ARF}_{3 \mathrm{~h}}=1.06\right), 6\left(\mathrm{ARF}_{6 \mathrm{~h}}=1.02\right)$, and $12 \mathrm{~h}\left(\mathrm{ARF}_{12 \mathrm{~h}}=1.01\right)$ durations. For the $24 \mathrm{~h}$ data, no adjustment is needed. For the hourly resolution we apply the $\mathrm{ARF}_{1 \mathrm{~h}}=1.279$ from Sunyer et al. (2016) following Wilson (1990).

In Austria and Slovenia, we use the ARFs by Breinl et al. (2020), which amount to $1.30(1.20,1.13,1.09,1.06)$ for hourly $(3,6,12,24 \mathrm{~h}$, respectively) duration. In the Italian provinces, the reduction factors by Mineo et al. (2018) are applied. These show a stronger reduction for shorter durations $\left(\mathrm{ARF}_{1 \mathrm{~h}}=1.52 ; \mathrm{ARF}_{3 \mathrm{~h}}=1.22 ; \mathrm{ARF}_{6 \mathrm{~h}}=1.07\right)$. For 12 and $24 \mathrm{~h}$ durations, Mineo et al. (2018) do not propose any reduction. As the areal correction is already implemented within the SHYPRE process chain of the French data, we only apply temporal correction factors of 1.03, 1.02, and 1.01 for hourly and 3 and $6 \mathrm{~h}$ durations following Berg et al. (2019). These temporal correction factors are also added to the ARFs of Wilson (1990), Breinl et al. (2020), and Mineo et al. (2018). An overview of the applied ARFs is given in Table 2.

For the combination of the overlapping national data sets, the mean of the two overlapping data sets is calculated.

\section{Results}

The median at each grid point of the 10-year return levels of hourly and $3,6,12$, and $24 \mathrm{~h}$ precipitation of the 50 CRCM5-LE members is generated and stored as commaseparated text files (Poschlod 2020). For each duration we store one file with five columns containing the return level based on the median of the 50-member CRCM5-LE and the $5 \%$ quantile and the $95 \%$ quantile of the ensemble at each grid cell as well as the geographical coordinates. We use this format because of a possible application within a nonscientific environment, whereas within climate science, the NetCDF format is widely used. Figure 1 shows the rainfall intensity for hourly and $12 \mathrm{~h}$ precipitation return levels for the European domain based on the median of the 50-member CRCM5-LE. Though covering the whole year, Fig. 1 can be compared to the 10-year return levels of nine RCM setups of the EURO-CORDEX ensemble, which were calculated for summertime precipitation only (Berg et al., 2019). We chose the same colour scaling for better comparability. The median return levels of the CRCM5-LE show a more homogeneous regional distribution with less scattering than the single RCM members in Berg et al. (2019). Also, single members of the CRCM5-LE show this smooth regional distribution, but the use of the median of 50 SMILE members enhances this behaviour, as it filters out the internal variability in the climate system within individual 30-year periods. For the hourly return levels, the combination of CanESM2 and CRCM5 shows relatively high intensities such as the two most intense model setups HIRHAM5-ECEARTH-r03 and REMO2009-MPI-ESM-RL in Berg et al. (2019). However, the spatial pattern differs, as the CRCM5-LE produces lower hourly rainfall intensities in the eastern part of the study area and shows a higher sensitivity to the topography of the Alps. In the central Alpine areas, the CRCM5-LE simulates very low hourly rainfall intensities of 6 to $15 \mathrm{~mm} \mathrm{~h}^{-1}$. The highest rainfall intensities are simulated south of the Alps and at the Adriatic coast.

For the $12 \mathrm{~h}$ duration, these areas also show the highest median rainfall intensities, with the Norwegian west coast and the Atlantic coast of northern Portugal and Spain also exhibiting high values. The lowest $12 \mathrm{~h}$ return levels are produced for the south-west and the north of the study area (northern Africa, UK, Scandinavia, and north-eastern Europe). The $12 \mathrm{~h} \mathrm{10-year} \mathrm{return} \mathrm{levels} \mathrm{based} \mathrm{on} \mathrm{the} \mathrm{median}$ of the CRCM5-LE are similar to all nine RCM-GCM combinations of Berg et al. (2019) in terms of spatial patterns as well as rainfall intensities. Hence, we argue that the differences between the parametrization of convection induces the big deviations within the hourly return levels, because for this duration convection is the main driver of extreme precipitation in large parts of Europe (Berg et al., 2013; Coppola et al., 2020; Lenderink and Meijgaard, 2008; Kendon et al., 2014).

In order to compare the return levels of the CRCM5-LE to observational data, we present both data sets as well as the percentage deviation in Figs. 2-4 for all durations.

The combined observational datasets (see Figs. 2-4) show quite smooth transitions between most of the different data sources and methods. The biggest deviation is found at the border of Norway and Sweden for hourly to $12 \mathrm{~h}$ durations (see Figs. 2 and 3), as the estimate of the rainfall return level 
Table 2. Applied areal reduction factors (ARFs) including temporal correction.

\begin{tabular}{lrrrrr}
\hline & $\mathrm{ARF}_{1 \mathrm{~h}}$ & $\mathrm{ARF}_{3 \mathrm{~h}}$ & $\mathrm{ARF}_{6 \mathrm{~h}}$ & $\mathrm{ARF}_{12 \mathrm{~h}}$ & $\mathrm{ARF}_{24 \mathrm{~h}}$ \\
\hline Germany & 1.32 & 1.06 & 1.02 & 1.01 & 1 \\
Austria & 1.34 & 1.24 & 1.14 & 1.09 & 1.06 \\
Belgium & 1.32 & 1.06 & 1.02 & 1.01 & 1 \\
France* & 1.03 & 1.02 & 1.01 & 1 & 1 \\
Switzerland & 1.32 & 1.06 & 1.02 & 1.01 & 1 \\
Norway & 1.32 & 1.06 & 1.02 & 1.01 & 1 \\
Slovenia & 1.34 & 1.24 & 1.14 & 1.09 & 1.06 \\
United Kingdom & 1.32 & 1.06 & 1.02 & 1.01 & 1 \\
Denmark & 1.32 & 1.06 & 1.02 & 1.01 & 1 \\
The Netherlands & 1.32 & 1.06 & 1.02 & 1.01 & 1 \\
Sweden & 1.32 & 1.06 & 1.02 & 1.01 & 1 \\
Finland & 1.32 & 1.06 & 1.02 & 1.01 & 1 \\
Italy & 1.56 & 1.24 & 1.08 & 1 & 1 \\
Spain & - & - & - & - & 1 \\
Portugal & - & - & - & - & 1 \\
Poland & - & - & - & - & 1 \\
\hline
\end{tabular}

* In France the areal reduction is implemented within the SHYPRE process chain. Only temporal correction factors are added.
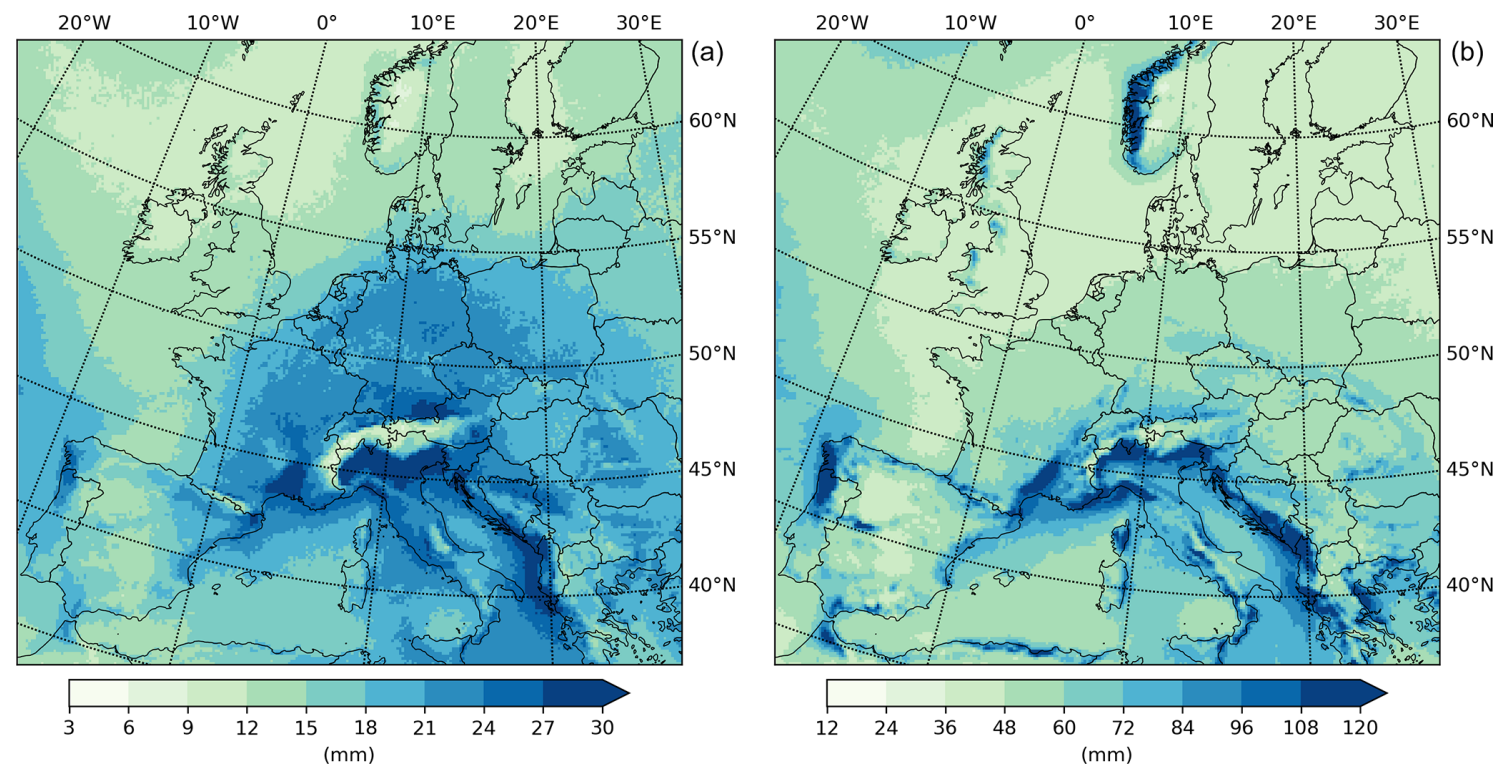

Figure 1. The 10-year return levels of hourly (a) and $12 \mathrm{~h}$ (b) precipitation over Europe based on the median of the 50-member CRCM5-LE.

for western Sweden by Olsson et al. (2018) is a lot higher than the estimate by Dyrrdal et al. (2015) for eastern Norway. This is due to the sparse sampling of observations and differing approaches to derive return levels (see Sect. 3.1). We also find slight deviations for the Netherlands, where the return levels by Beersma et al. (2018) are higher than the surrounding levels for northern Belgium and western Germany. For the shorter durations of hourly and $3 \mathrm{~h}$ return levels (see Fig. 2), deviations occur at the border between Italy and France as well as between Italy and Switzerland. This is due to the higher ARF applied in Italy (see Sect. 3.2). These deviations emphasize the need for homogeneous data sets of extreme precipitation.

As the 50 members of the CRCM5-LE also provide a range of equally probable estimations of return levels, we hatch areas where the observations are not within the range of the regional climate model ensemble. The rainfall intensity of the observational data set is within the range of the climate-model-generated intensities in $60 \%(77 \%, 78 \%$, $83 \%, 78 \%)$ of the area for hourly $(3,6,12,24 \mathrm{~h})$ durations (see Figs. 2-4). This fraction of areas gradually increases between hourly and $12 \mathrm{~h}$ durations, whereas it slightly de- 

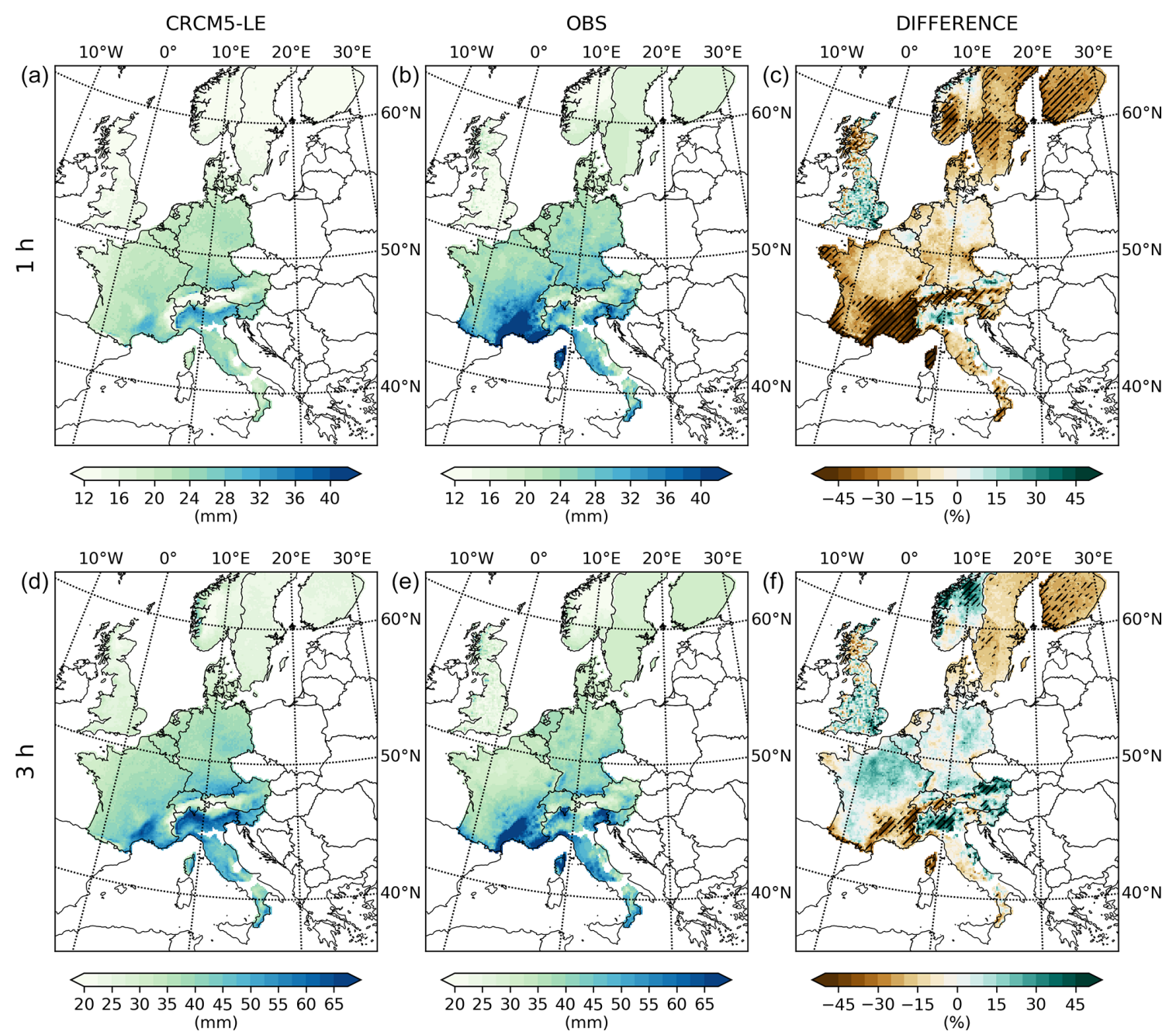

Figure 2. The 10-year return levels of hourly (a-c) and $3 \mathrm{~h}(\mathbf{d}-\mathbf{f})$ precipitation over parts of Europe. The CRCM5-LE data (a, d) are compared to an observational data set $(\mathbf{b}, \mathbf{e})$, and the percentage deviation $(\mathbf{c}, \mathbf{f})$ is shown. Areas where the observations are not in the range of the CRCM5-LE are hatched.

creases for the $24 \mathrm{~h}$ duration. For the $24 \mathrm{~h}$ return period, data for the Iberian Peninsula and Poland were added, whereas no data for these countries were available for the hourly to $12 \mathrm{~h}$ evaluation. Without these additional data sets, the fraction of areas where $24 \mathrm{~h}$ observational return levels are within the CRCM5-LE return levels would amount to $80 \%$. In addition, in the Netherlands, Switzerland, and Norway, different databases are used for the estimations of the return levels of hourly to $12 \mathrm{~h}$ durations and the $24 \mathrm{~h}$ duration (see Sect. 3 ).

The hourly intensities are generally underestimated by the CRCM5-LE except for England and Wales, northern Italy, northern Austria, and the northern part of Norway, resulting in an areal average bias of $-16.3 \%$ (see Fig. 2). There is also an area-wide underestimation in the Mediterranean as well as in Scandinavia in all 50 members of the large ensemble, which is why the observations are not in the range of the CRCM5-LE for large parts of these areas (see Fig. 2). For durations of 3 to $12 \mathrm{~h}$, the biases over the whole area de- crease to $-1.0 \%,-0.5 \%$, and $+0.1 \%$ (see Figs. 2 and 3). The high intensities of southern France, southern Switzerland, and parts of Italy are underestimated (see Figs. 2 and 3). Also in Sweden and Finland the observational data sets report higher rainfall intensities. For the $24 \mathrm{~h}$ aggregation, the bias amounts to $+8.2 \%$ (see Fig. 4). The CRCM5 overestimates $24 \mathrm{~h}$ rainfall intensities in western Norway and at the Atlantic coast of the northern Iberian Peninsula, which is why the observations are not in the range of the 50 CRCM-LE members (see Fig. 4).

We calculate Spearman's rank correlation coefficient $\rho$ as a measure to compare the spatial patterns. For the median of the return levels of the CRCM5-LE and the observational data, the coefficient amounts to $0.83(0.81,0.76,0.78,0.83$, respectively) of the area for hourly $(3,6,12,24 \mathrm{~h}$, respectively) durations. These values confirm the visual impression of a high spatial pattern correlation when comparing both data sets (see Figs. 2-4). 

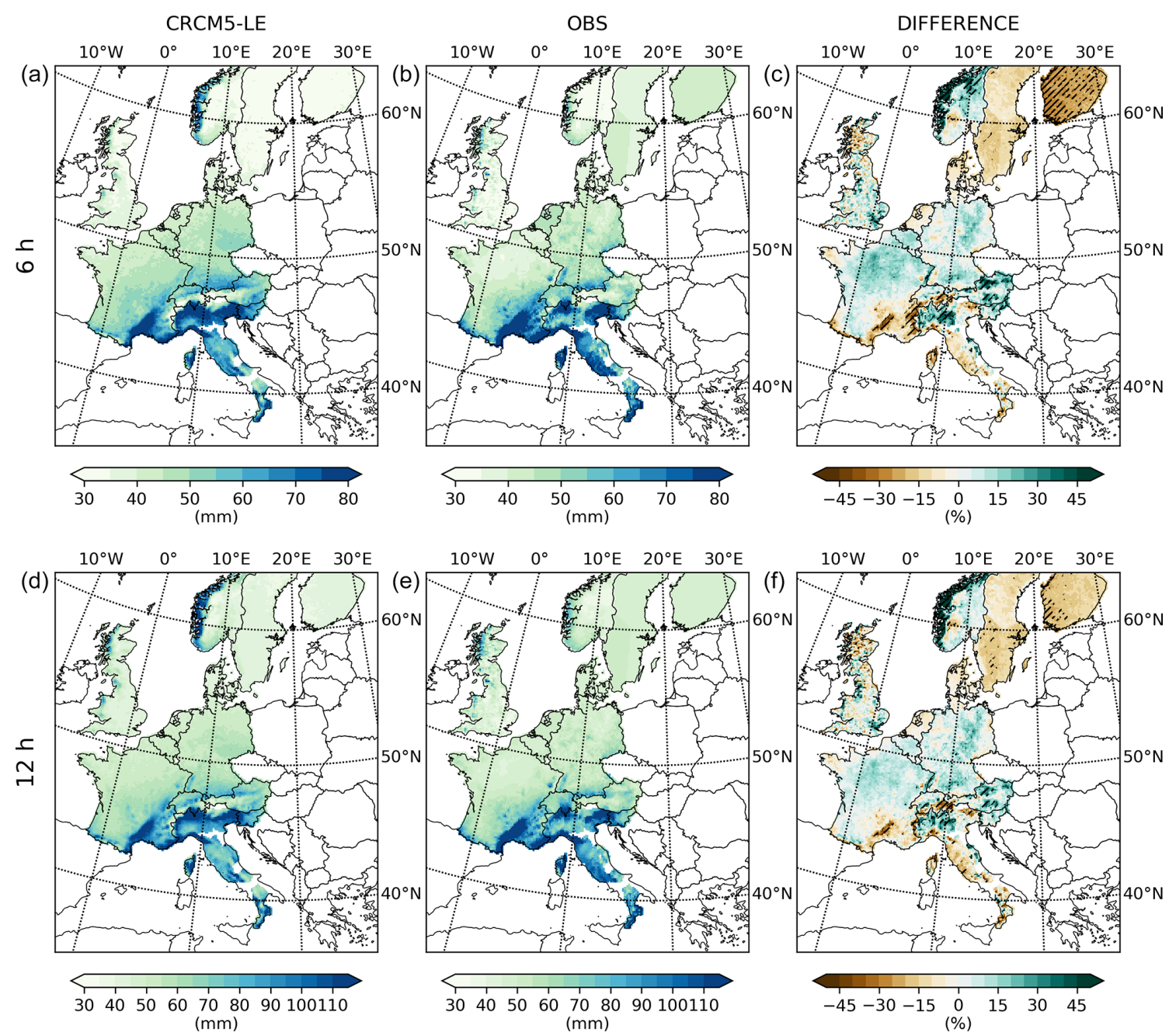

Figure 3. The 10-year return levels of $6(\mathbf{a}-\mathbf{c})$ and $12 \mathrm{~h}(\mathbf{d}-\mathbf{f})$ precipitation over parts of Europe. The CRCM5- LE data (a, d) are compared to an observational data set $(\mathbf{b}, \mathbf{e})$, and the percentage deviation $(\mathbf{c}, \mathbf{f})$ is shown. Areas where the observations are not in the range of the CRCM5-LE are hatched.

\section{Discussion}

Generally, the overall low bias of the return levels based on climate model data as well as the high spatial correlation between the observational and modelled return levels proves that the CRCM5-LE is able to capture the features of the heterogeneous set of drivers which govern the European climate of heavy and extreme precipitation.

Especially for countries without any sub-daily precipitation measurement, the data set based on climate model simulations can provide valuable estimations. But also for countries offering return levels of extreme sub-daily precipitation, our results show that the sparse observational network can be supported by climate model simulations. Accordingly, the Austrian return level data (Sect. 3.1) are supplemented by a convective-permitting weather model (Kainz et al., 2007).

\subsection{Uncertainties in observational data}

Due to differing methods, temporal resolutions of the rain gauges, available time periods, and areal coverage, we do not regard the combined observational data set as "truth" but as the largest possible comparison product, which is directly based on hourly observations. The uncertainties within these data are caused by different sources. First, the rain gauge measurements systematically underestimate precipitation due to splashing raindrops, wetting of the funnel surface, evaporation from the funnel, and wind effects (Førland et al., 1996; Richter, 1995; Westra et al., 2014). The choice of the sampling approach as well as the choice of the extreme value distribution leads to differing estimations of return levels (Lazoglou and Anagnostopoulou, 2017). Also, the fitting of the parameters of the respective extreme value distribution to the extreme-precipitation samples induces additional uncertainty (Muller et al., 2009). As described in Sect. 3.1, the 

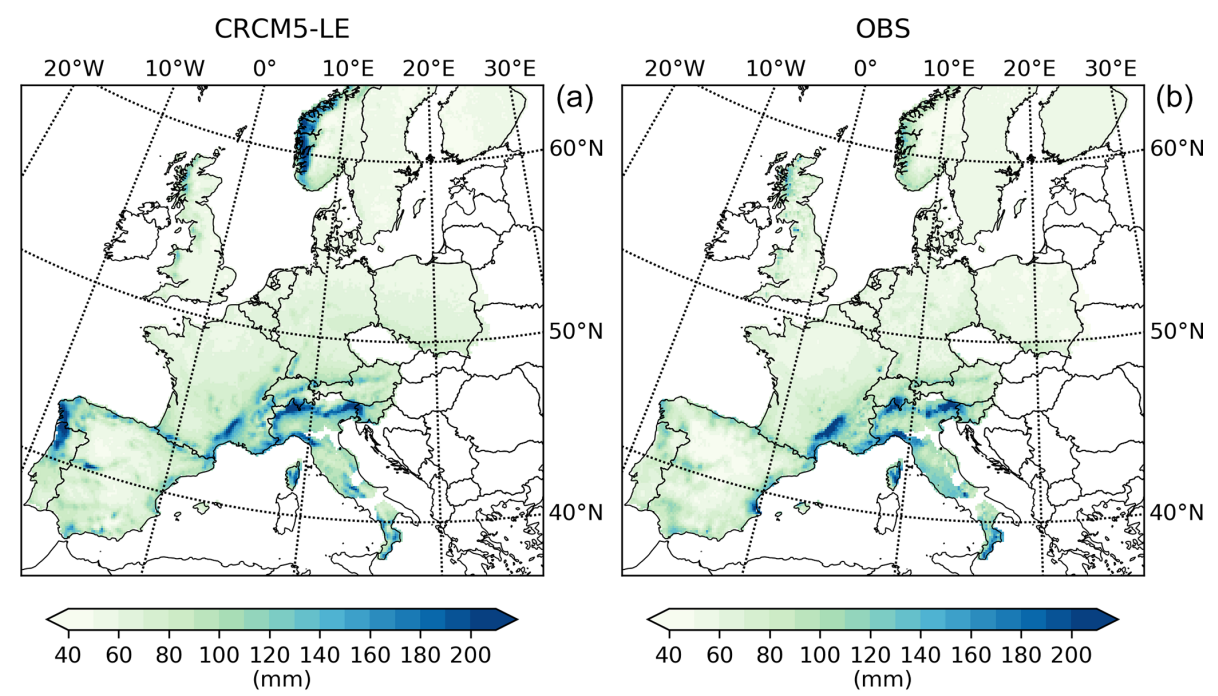

DIFFERENCE

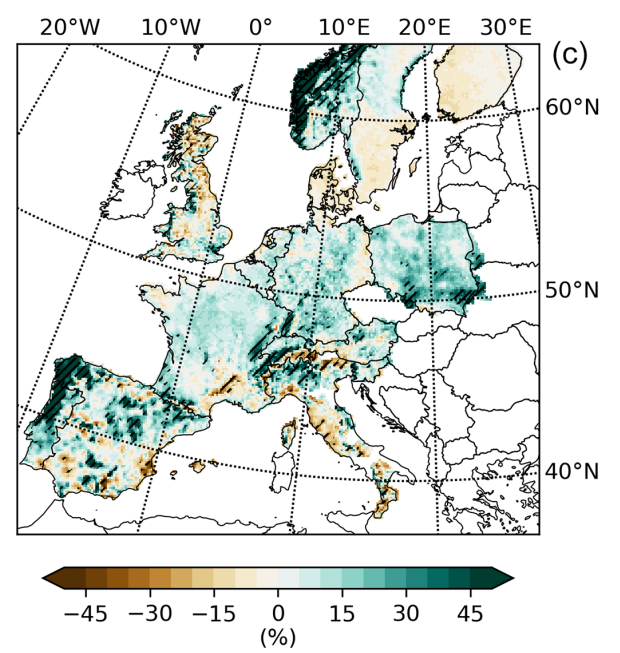

Figure 4. The 10-year return levels of $24 \mathrm{~h}$ precipitation over parts of Europe. The CRCM5-LE data (a) are compared to an observational data set (b), and the percentage deviation (c) is shown. Areas where the observations are not in the range of the CRCM5-LE are hatched.

applied EVT approaches differ for the national data sets. Lazoglou and Anagnostopoulou (2017) have shown that the estimations of 50-year return levels of daily precipitation at 10 different Mediterranean stations differ by between $5 \%$ and $15 \%$ according to the application of GEV or GPD and three different fitting methods.

The national data sets of Norway and Germany do not refer to all seasons but cover only summertime events (Dyrrdal et al., 2015; Malitz and Ertel, 2015). The available time periods of observations not only differ for all countries but also differ within the countries, as new rain gauges were installed over time and other measurement stations were discarded. Short time periods increase the uncertainties in the parameter fits of the extreme value distribution (Cai and Hames, 2011). Additionally, extreme precipitation, especially when caused by convectional processes, is spatially highly vari- able (Zolina et al., 2014). Therefore, the representativeness of single-point observations is limited.

Transferring these rather uncertain point-scale observation-based data to areal estimates can be carried out with various spatial interpolation methods such as inverse distance weighting; multivariate splines, machine learning approaches; or different versions of kriging, where auxiliary geographical or climatological covariates can be added via regression fields (e.g. Malitz and Ertel, 2015; van de Vyver, 2012). In combination with low spatial coverage of the rain gauges (Isotta et al., 2014), this step induces additional methodological uncertainties. The regionalization of extreme precipitation is subject to a wide field of research, where many sophisticated methods are applied that show different interpolation results (Hu et al., 2019). Because for most countries only the return level itself and not the time 
series of rainfall is provided, we applied ordinary kriging to regionalize the observational point data.

The linear scaling to the $0.11^{\circ}$ CRCM5-LE grid was applied to the national data, which are provided as areal estimates with different spatial resolutions. The aggregation and linear scaling to the spatial resolution of $0.11^{\circ}$ smooths extreme values of single grid cells.

The last step to make observation data and climate model data comparable features the application of the areal reduction factor (ARF). The ARFs are derived empirically and therefore differ between different studies, which also causes uncertainty (Berg et al., 2019; Sunyer et al., 2016; Wilson, 1990).

Junghänel et al. (2017) estimate a tolerance range of $\pm 15 \%$ for 10 -year return levels of the German national data (Sect. 3.1.1).

Even though the combined observational data set is subject to different limitations and uncertainties, it is a necessary approach not only to evaluate the return levels of climate models locally or countrywide but also to perform validation at an (almost) continental scale. To our knowledge, such an assessment has not been carried out before. The confidence level in this validation varies by country depending on the underlying rainfall database and the procedure of the return level calculation, which has been described in Sect. 3. The obvious deviations in our homogenized observational return level product at the country borders between Norway and Sweden and between Italy, France, and Switzerland as well as between the Netherlands, Germany, and Belgium (as described in Sect. 4) show that the validation in these regions is subject to major uncertainties for hourly to $12 \mathrm{~h}$ durations. On the other hand, the good fit and the preservation of topographic features at the borders of Germany, Denmark, Belgium, France, Austria, Switzerland, and Slovenia support the confidence level in the validation for these regions. For the $24 \mathrm{~h}$ duration we find no major deviations along the country borders, which increases the confidence in this return level duration.

\subsection{Natural variability within the CRCM5-LE}

Extreme precipitation events show a high variability due to the natural variability in the climate system (Aalbers et al., 2018). By the application of a 50-member SMILE, we assume the range of natural variability in extreme rainfall to be represented by the ensemble (Deser et al., 2012; Hawkins and Sutton, 2009; von Trentini et al., 2019). In consequence, while all 50 members are forced by the same emissions and are simulated by the same model structure and physics, the resulting return levels differ from each other.

In order to visualize this range, we show the standard deviation, as well as the $5 \%$ and $95 \%$ quantiles of all 50 members at each grid cell representing the 10-year return level of $3 \mathrm{~h}$ precipitation (Fig. 5). The standard deviation amounts to $3.33 \mathrm{~mm}$ as the areal average. The $5 \%$ - and $95 \%$-quantile return levels differ by -4.7 and $+5.8 \mathrm{~mm}$ from the median, respectively, which equals a percentage range of $-14 \%$ to $+17 \%$. This range is quite stable for other durations as well $(-15 \%$ to $+18 \%$ for hourly and $-15 \%$ to $+14 \%$ for 6 , $-14 \%$ to $+17 \%$ for 12 , and $-13 \%$ to $+17 \%$ for $24 \mathrm{~h} \mathrm{du}-$ rations). Thereby, the overall variability is mainly caused by natural variability in the rainfall intensity. The spatial patterns of the minimum and maximum estimates show high agreement with a Spearman's rank correlation coefficient of $\rho=0.91$. Hence, we conclude that the application of annual maxima of 30-year periods and EVT can filter out the spatial variability in single extreme events, but the estimates of 10year return levels are still governed by the natural variability within the 30-year periods.

For a local-scale visualization, we provide the range of the CRCM5-LE return levels as well as the observational return levels for all considered durations at six different European cities (see Fig. 6). Oslo, London, Brussels, Paris, Munich, and Rome show different climates and distances to the ocean. We also include the city of Rome as an example of where the observational data are not within the range of the climate model simulations. We find that the absolute range of natural variability is dependent on the intensity of rainfall, which is also visible in the standard deviation in Fig. 5 . We argue that convective processes are more affected by natural variability and, therefore, the return levels in Rome and Paris show greater variability than in Oslo or London.

Due to the application of a SMILE, natural variability in return levels of extreme rainfall can now be quantitatively assessed at local, regional, and continental scales. Before, it had been included within uncertainty estimations of observational return levels as an additional source of uncertainty (Junghänel et al., 2017) but was only estimated rather arbitrarily.

\subsection{Limitations of the CRCM5-LE}

In general, the results of the CRCM5-LE are governed by model uncertainty, as the ensemble only features one combination of GCM and RCM. Different model combinations or even modifications of the dynamics, physics, and structure of the same climate models would yield different return level estimates. The results of the study by Berg et al. (2019) suggest that the influence on the return level estimates of the RCM is significantly greater than that of the atmospheric forcing by the GCM.

The return levels simulated by the CRCM5-LE are limited by the spatial resolution of the model setup, by the temporal resolution of the stored precipitation output, and by the non-explicit calculation of convectional precipitation using parametrization schemes. Short-duration rainfall extremes over Europe are mainly governed by convectional processes, which can only be resolved by regional climate models with explicit convection schemes, i.e. spatial resolutions of $4 \mathrm{~km}$ or less (Tabari et al., 2016). Prein et al. (2015) have shown that improved spatial resolution also leads to 


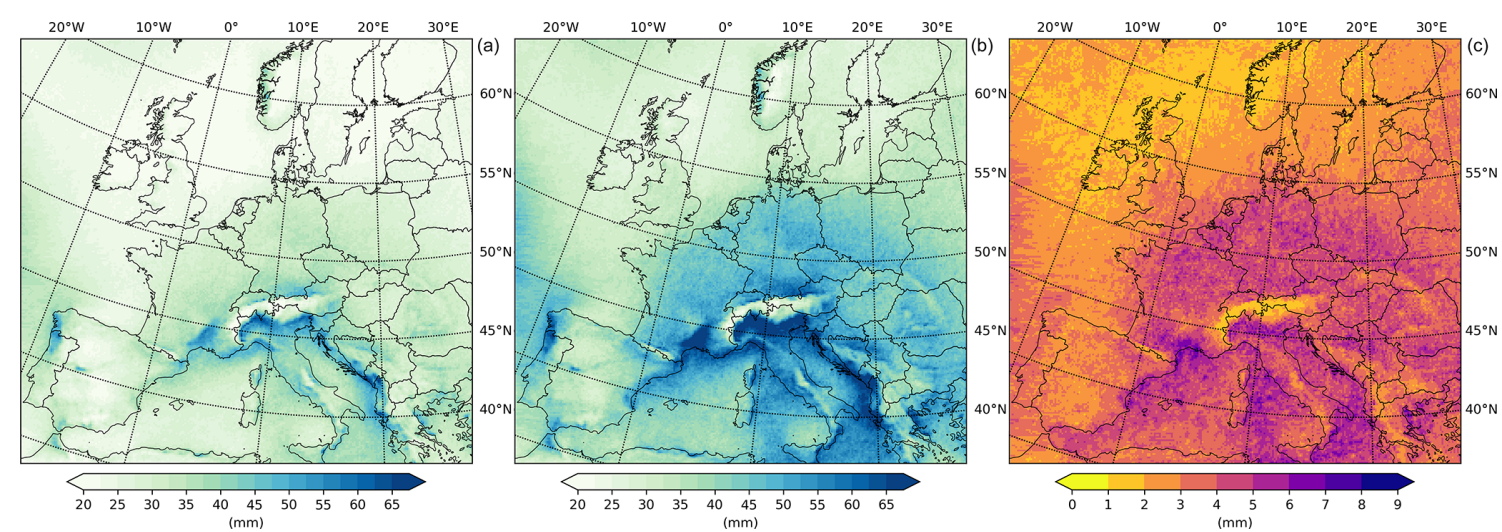

Figure 5. The $5 \%$ quantile (a), $95 \%$ quantile, (b) and standard deviation (c) of the 50 CRCM5-LE members for 10-year return levels of $3 \mathrm{~h}$ precipitation over Europe.
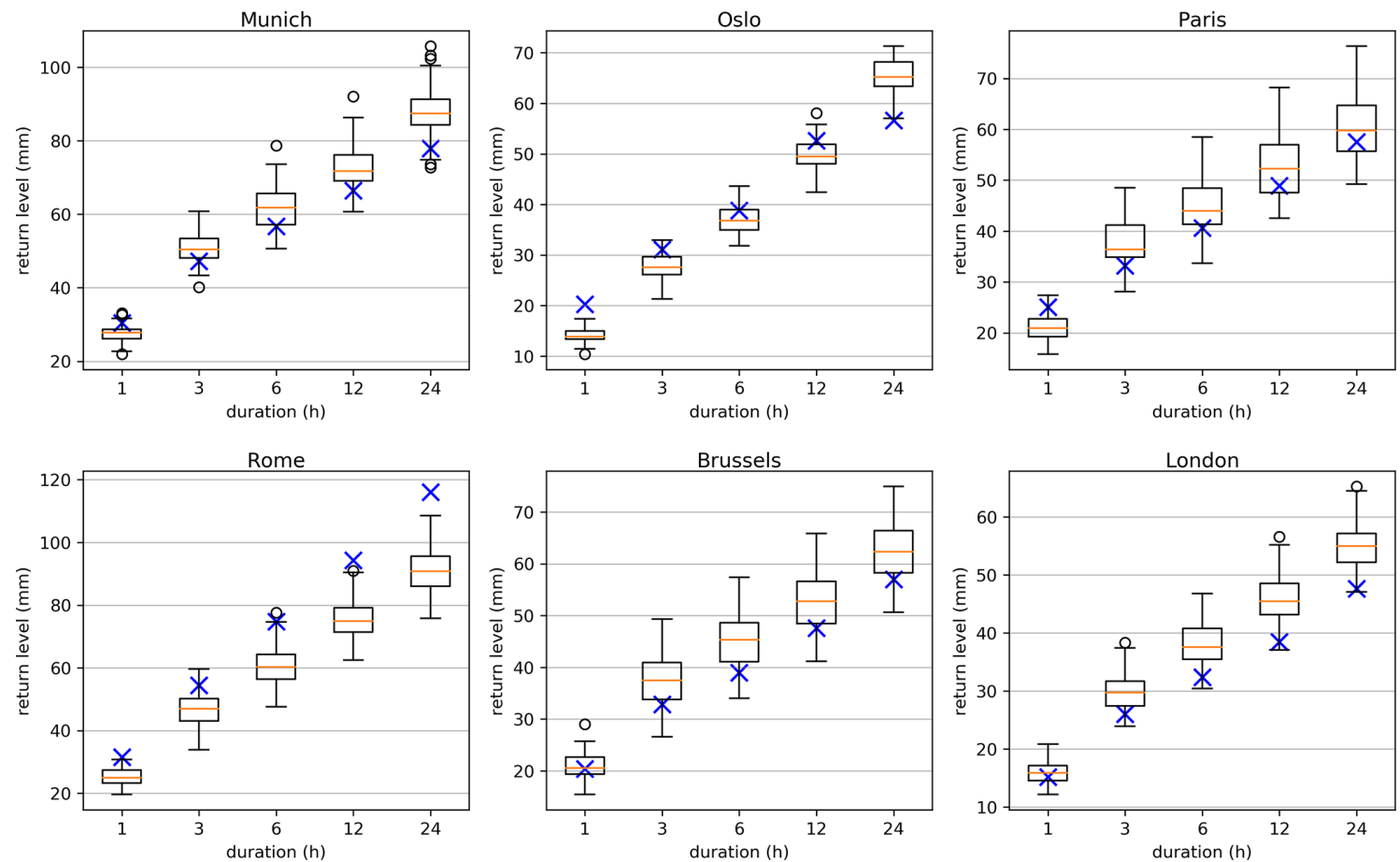

Figure 6. The range of the 10-year return levels of the CRCM5-LE at six cities is shown as box plots, where the median corresponds to the orange line. The boxes are defined by the first and third quartiles. Outliers exceed the first or third quartile plus 1.5 times the interquartile range. They are depicted as black circles. The observational return levels are marked as blue crosses.

better reproduction of convectional rainfall. Several studies have reported that the application of convection-permitting models (CPMs) improves the reproduction of heavy-rainfall events over Europe (Berthou et al., 2020; Kendon et al., 2014, 2017; Poschlod et al., 2018). In addition to the benefit of explicitly calculating convection, complex topography is better resolved with a better spatial resolution. The $0.11^{\circ}$ resolution of the CRCM5-LE equals around $12.5 \mathrm{~km}$, which leads to systematic shifts in the location of high orographic precipitation. This phenomenon is visible for steep mountainous slopes with a westward exposition, such as the Black Forest in south-western Germany or the Apennines in central Italy (see Fig. 3). The CRCM5-LE simulates the areas of highintensity orographically enhanced precipitation one to two grid cells further to the west than the observational data set. These deviations do not affect the bias as a quality measure, as the areal average intensity is reproduced, but the location is not correctly estimated. However, the centred Spearman product-moment coefficient includes these local deviations. We argue that a higher spatial resolution would be able to lower these errors. 
Generally, the CRCM5-LE setup shows a high sensitivity to orographic features, as the return levels at the central Alpine areas are simulated with lower intensities than the selection of EURO-CORDEX RCMs by Berg et al. (2019). Observations also show an intense gradient from high-intensity rainfall at the Alpine slopes and low-intensity precipitation in the inner Alps. However, the area of low-intensity rainfall is smaller than simulated by the CRCM5 (see Figs. 2-4).

The already-existing 30-member CPM multimodel ensemble (Coppola et al., 2020) has provided promising results for convective events over complex topography in Europe. However, the inter-model spread is governed by model uncertainty as well as by natural variability. We conclude that a convection-permitting version of SMILE is needed to improve the reproduction of sub-daily convectional extreme rainfall, to resolve complex topography over Europe, and to disentangle natural variability and model uncertainty. As even the simulation of the 50-member SMILE with a $0.11^{\circ}$ spatial resolution was very cost-intensive in terms of computing power and data storage, a CPM SMILE would place high demands on high-performance computing centres.

\section{Code availability}

The underlying software code is not publicly available because it relates to a very large number of local files (netCDF, Excel, PDF, txt files by the meteorological offices, GIS shapefiles and masks for countrywide return levels), which are needed to compile the code. Furthermore, some underlying observation-based datasets have been made available for (personal) scientific use only.

\section{Data availability}

Data are accessible under the Creative Commons Attribution 4.0 International Public License (Poschlod, 2020; https://doi.org/10.5281/zenodo.3878887).

\section{Summary and conclusion}

We provide a data set of 10-year return levels of hourly to $24 \mathrm{~h}$ rainfall over Europe. The results are compared to an observation-based return level product, which was combined using several national or even sub-national data sets. The CRCM5 setup has shown good agreement with the observational data for large parts of the study area in terms of bias and spatial correlation, with the highest agreement for 3 to $24 \mathrm{~h}$ durations. The application of a SMILE has enabled us to assess the impact of natural variability on the estimation of sub-daily rainfall return periods. The range of natural variability has to be added as uncertainty range to any observational data set, as the observed weather can be interpreted as only one possible realization of the climate within the ranges of natural variability in the climate system.
The provided data are a good source of information for countries with low observational coverage of sub-daily rainfall. Although we do not necessarily recommend applying the data to the planning and design of infrastructure, as the model results are governed by the limitations of temporal and spatial resolution and parametrization of convection, we conclude that the study delivers a homogenized data set of subdaily heavy precipitation across most of Europe and supports an improved description and understanding of precipitation dynamics in a high resolution. Given the very promising findings of our study and acknowledging its observable limitations, we argue that a convection-permitting single-model initial-condition large ensemble would be very valuable to further improving the analysis of extreme precipitation and its natural variability.

We conclude with the serious demand that sub-daily observational data should be homogeneously processed, registered, and stored centrally with public access, at least for scientific applications. Even the national data sets, which are publicly available already, are very difficult to find and access due to the restrictions reported in Sect. 3. We hope that the Global Sub-Daily Rainfall Dataset (GSDR; Lewis et al., 2019a) can start to bridge these gaps, and we encourage all meteorological offices to provide their data.

Supplement. The supplement related to this article is available online at: https://doi.org/10.5194/essd-13-983-2021-supplement.

Author contributions. BP, JS, and RL designed the concept of the study. BP carried out the data analysis and the visualization. $\mathrm{BP}$ prepared the manuscript with contributions from both other coauthors.

Competing interests. The authors declare that they have no conflict of interest.

Acknowledgements. We cordially thank all the meteorological offices and study authors that calculated and provided the observational rainfall data: Aaltonen et al. (2008); Arnaud et al. (2008); ARPA Calabria; ARPA Friuli Venezia Giulia; ARPA Liguria; ARPA Piemonte; ARPA Veneto; Beersma et al. (2018); BeloPereira et al. (2011); Berezowski et al. (2015); Bundesministerium für Landwirtschaft, Regionen und Tourismus, Austria; Centro Funzionale Regionale Autonoma Valle d'Aosta; Centro Funzionale Regionale - Regione Lazio; Deutscher Wetterdienst; Dyrrdal et al. (2015); Météo-France; Herrera et al. (2012); Instituto Português do Mar e da Atmosfera; Kainz et al. (2007); Koninklijk Nederlands Meteorologisch Instituut; Lewis et al. (2019b); Lussana and Tveito (2017); Madsen et al. (2017); Malitz and Ertel (2015); Manfreda et al. (2015); MeteoSwiss, Meteotrentino; de Michele et al. (2005); Morbidelli et al. (2016); MET Norway as well as the Norwegian Computing Center; Olsson et al. (2018); Protezione Civile Regionale Marche; Protezione Civile Regione Molise; Royal Mete- 
orological Institute of Belgium; Regione Toscana; Slovenian Environment Agency; Santander Meteorology Group; Venäläinen et al. (2007); and van de Vyver (2012).

We thank all members of the ClimEx project working group for their contributions to producing and analysing the CanESM2LE and CRCM5-LE. The ClimEx project is funded by the Bavarian State Ministry of the Environment and Consumer Protection. The CRCM5 was developed by ESCER of the Universite du Québec à Montréal (UQAM; http://www.escer.uqam.ca, last access: 8 March 2021) in collaboration with Environment and Climate Change Canada. We thank the Canadian Centre for Climate Modelling and Analysis (CCCma) for executing and making available the CanESM2 Large Ensemble simulations used in this study, and we thank the Canadian Sea Ice and Snow Evolution (CanSISE) Network for proposing the simulations. Computations with the CRCM5 for the ClimEx project were made on the SuperMUC supercomputer at the Leibniz Supercomputing Centre (LRZ) of the Bavarian Academy of Sciences and Humanities. The operation of this supercomputer is funded via the Gauss Centre for Supercomputing (GCS) by the German Federal Ministry of Education and Research and the Bavarian State Ministry of Education, Science and the Arts.

Financial support. This research has been supported by the Bavarian Environment Agency (grant no. 81-0270-82467/2019) and the Research Council of Norway (grant no. 250573).

Review statement. This paper was edited by David Carlson and reviewed by Hossein Tabari and one anonymous referee.

\section{References}

Aalbers, E. E., Lenderink, G., van Meijgaard, E., and van den Hurk, B. J. J. M.: Local-scale changes in mean and heavy precipitation in western Europe, climate change or internal variability?, Clim. Dynam., 50, 4745-4766, https://doi.org/10.1007/s00382017-3901-9, 2018.

Aaltonen, J., Hohti, H., Jylhä, K., Karvonen, T., Kilpeläinen, T., Koistinen, J., Kotro, J., Kuitunen, T., Ollila, M., Parvio, A., Pulkkinen, S., Silander, J., Tiihonen, T., Tuomenvirta, H., and Vajda, A.: Rankkasateet ja taajamatulvat (RATU), Tech. Rep., Helsinki, Finland, 126 pp., 2008.

Addor, N. and Fischer, E. M.: The influence of natural variability and interpolation errors on bias characterization in RCM simulations, J. Geophys. Res.-Atmos., 120, 180-195, https://doi.org/10.1002/2014JD022824, 2015.

Arnaud, P. and Lavabre, J.: Coupled rainfall model and discharge model for flood frequency estimation, Water Resour. Res., 38, 1-11, https://doi.org/10.1029/2001WR000474, 2002.

Arnaud, P., Lavabre, J., Sol, B., and Desouches, C.: Régionalisation d'un générateur de pluies horaires sur la France métropolitaine pour la connaissance de l'aléa pluviographique/Regionalization of an hourly rainfall generating model over metropolitan France for flood hazard estimation, Hydrol. Sci. J., 53, 34-47, https://doi.org/10.1623/hysj.53.1.34, 2008.

Arnbjerg-Nielsen, K., Willems, P., Olsson, J., Beecham, S., Pathirana, A., Gregersen, I. B., Madsen, H., and Nguyen, V. T.
V.: Impacts of climate change on rainfall extremes and urban drainage systems: a review, Water Sci. Technol., 68, 16-28, https://doi.org/10.2166/wst.2013.251, 2013.

Arora, V. K., Scinocca, J. F., Boer, G. J., Christian, J. R., Denman, K. L., Flato, G. M., Kharin, V. V., Lee, W. G., and Merryfield, W. J.: Carbon emission limits required to satisfy future representative concentration pathways of greenhouse gases, Geophys. Res. Lett., 38, L05805, https://doi.org/10.1029/2010GL046270, 2011.

ARPACAL (ARPA Calabria): Consultazioni Banca Dati Storici, http://www.cfd.calabria.it/index.php/dati-stazioni/dati-storici, last access: 30 January 2020.

ARPAFVG (ARPA Friuli Venezia Giulia): ARPA FVG meteo, https://www.osmer.fvg.it/clima.php?ln=, last access: 10 January 2020.

ARPAL (ARPA Liguria): Atlante Climatico Della Liguria, Tech. Rep., Genova, Italy, 130 pp., 2013.

ARPAP (ARPA Piemonte): Accesso ai dati "Annali meteorologici ed idrologici" Banca dati meteorologica, https: //www.arpa.piemonte.it/rischinaturali/accesso-ai-dati/annali_ meteoidrologici/annali-meteo-idro/banca-dati-meteorologica. html, last access: 20 January 2020.

ARPAV (ARPA Veneto): Dati delle precipitazioni di massima intensità, https://www.arpa.veneto.it/bollettini/storico/precmax/, last access: 3 January 2020.

Barbero, R., Fowler, H. J., Blenkinsop, S., Westra, S., moron, V., Lewis, E., Chan, S., Lenderink, G., Kendon, E., Guerreiro, S., Li, X.-F., Villalobos, R., Ali, H., and Mishra, V.: A synthesis of hourly and daily precipitation extremes in different climatic regions, Weather. Clim. Extremes, 26, 100219, https://doi.org/10.1016/j.wace.2019.100219, 2019.

Barredo, J. I.: Normalised flood losses in Europe: 19702006, Nat. Hazards Earth Syst. Sci., 9, 97-104, https://doi.org/10.5194/nhess-9-97-2009, 2009.

Beersma, J., Versteeg, R., and Hakvoort, H.: Neerslagstatistieken voord korte duren, Tech. Rep., STOWA, Amersfoort, the Netherlands, 58 pp., 2018.

Bélair, S., Mailhot, J., Girard, C., and Vaillancourt, P.: Boundary layer and shallow cumulus clouds in a medium-range forecast of a large-scale weather system, Mon. Weather Rev., 133, 19381960, https://doi.org/10.1175/MWR2958.1, 2005.

Belo-Pereira, M., Dutra, E., and Viterbo, P.: Evaluation of global precipitation data sets over the Iberian Peninsula, J. Geophys. Res., 116, D20101, https://doi.org/10.1029/2010JD015481, 2011.

Benjamini, Y. and Hochberg, Y.: Controlling the false discovery rate - a practical and powerful approach to multiple testing, J. Roy. Stat. Soc. B., 57, 289-300, https://doi.org/10.1111/j.25176161.1995.tb02031.x, 1995.

Benoit, R., Côté, J., and Mailhot, J.: Inclusion of a TKE boundary layer parameterization in the Canadian regional finite-element model, Mon. Weather Rev., 117, 1726-1750, https://doi.org/10.1175/15200493(1989)117<1726:IOATBL>2.0.CO;2, 1989.

Berezowski, T., Piniewski, M., Szcześniak, M., Kardel, I., and Michałowski R.: CHASE-PL Forcing Data: Gridded Daily Precipitation \& Temperature Dataset $5 \mathrm{~km}$ (CPLFDGDPT5). Warsaw University of Life Sciences WULS-SGGW, 
Dataset, https://doi.org/10.4121/uuid:e939aec0-bdd1-440fbd1e-c49ff10d0a07, 2015.

Berezowski, T., Szcześniak, M., Kardel, I., Michałowski, R., Okruszko, T., Mezghani, A., and Piniewski, M.: CPLFDGDPT5: High-resolution gridded daily precipitation and temperature data set for two largest Polish river basins, Earth Syst. Sci. Data, 8, 127-139, https://doi.org/10.5194/essd-8-127-2016, 2016.

Berg, P., Moseley, C., and Haerter, J. O.: Strong increase in convective precipitation inresponse to higher temperatures, Nat. Geosci., 6, 181-185, https://doi.org/10.1038/ngeo1731, 2013.

Berg, P., Christensen, O. B., Klehmet, K., Lenderink, G., Olsson, J., Teichmann, C., and Yang, W.: Summertime precipitation extremes in a EURO-CORDEX $0.11^{\circ}$ ensemble at an hourly resolution, Nat. Hazards Earth Syst. Sci., 19, 957-971, https://doi.org/10.5194/nhess-19-957-2019, 2019.

Berthou, S., Kendon, E. J., Chan, S. C., Ban, N., Leutwyler, D., Schär, C., and Fosser, G.: Pan-European climate at convectionpermitting scale: a model intercomparison study, Clim. Dynam., 55, 35-59, https://doi.org/10.1007/s00382-018-4114-6, 2020.

Bevacqua, E., Maraun, D., Hobæk Haff, I., Widmann, M., and Vrac, M.: Multivariate statistical modelling of compound events via pair-copula constructions: analysis of floods in Ravenna (Italy), Hydrol. Earth Syst. Sci., 21, 2701-2723, https://doi.org/10.5194/hess-21-2701-2017, 2017.

Bevacqua, E., Maraun, D., Vousdoukas, M., Voukouvalas, E., Vrac, M., Mentaschi, L., and Widmann, M.: Higher potential compound flood risk in northern Europe under anthropogenic climate change, Sci. Adv., 5, eaaw5531, https://doi.org/10.1126/sciadv.aaw5531, 2019.

BMLRT (Bundesministerium für Landwirtschaft, Regionen und Tourismus): Forschungsprojekt "Bemessungsniederschläge in der Siedlungswasserwirtschaft”, Tech. Rep., Vienna, Austria, 79, 2006.

BMLRT (Bundesministerium für Landwirtschaft, Regionen und Tourismus): eHYD, https://ehyd.gv.at/, last access: 22 October 2019.

Boughton, W. and Jakob, D.: Adjustment factors for restricted rainfall, Aust. J. Water Resour., 12, 37-47, https://doi.org/10.1080/13241583.2008.11465332, 2008.

Breinl, K., Müller-Thomy, H., and Blöschl, G.: Space-Time Characteristics of Areal Reduction Factors and Rainfall Processes, J. Hydrometeorol., 21, 671-689, https://doi.org/10.1175/JHM-D19-0228.1, 2020.

Bresson, É., Laprise, R., Paquin, D., Thériault, J. M., and de Elía, R.: Evaluating the Ability of CRCM5 to Simulate Mixed Precipitation, Atmos. Ocean, 55, 2, 79-93, https://doi.org/10.1080/07055900.2017.1310084, 2017.

Bruni, G., Reinoso, R., van de Giesen, N. C., Clemens, F. H. L. R., and ten Veldhuis, J. A. E.: On the sensitivity of urban hydrodynamic modelling to rainfall spatial and temporal resolution, Hydrol. Earth Syst. Sci., 19, 691-709, https://doi.org/10.5194/hess19-691-2015, 2015.

Cai, Y. and Hames, D.: Minimum Sample Size Determination for Generalized Extreme Value Distribution, Commun. Stat. Simul. C, 40, 87-98, https://doi.org/10.1080/03610918.2010.530368, 2011.
CFRAVA (Centro Funzionale Regionale Autonomico Valle d'Aosta): Portale dati, available at: https://cf.regione.vda.it/ portale_dati.phpTS27, last access: 5 January 2020.

CFRRL (Centro Funzionale Regionale: Regione Lazio): Curve di possibilità pluviometrica (aggiornamento maggio 2018), http://www.idrografico.regione.lazio.it/std_page.aspx-Page= curve_pp.htm (last access: 8 January 2020), May 2018.

Chen, G. and Balakrishnan, N.: A general purpose approximate goodness-of-fit test, J. Qual. Technol., 27, 154-161, https://doi.org/10.1080/00224065.1995.11979578, 1995.

Cohen, J., Ye, H., and Jones, J.: Trends and variability in rain-on-snow events, Geophys. Res. Lett., 42, 7115-7122, https://doi.org/10.1002/2015GL065320, 2015.

Coles, S.: An introduction to statistical modeling of extreme values, Springer, London, UK, 2001.

Coppola, E., Sobolowski, S., Pichelli, E., Raffaele, F., Ahrens, B., Anders, I., Ban, N., Bastin, S., Belda, M., Belušić, D., CaldasAlvarez, A., Cardoso, R. M., Davolio, S., Dobler, A., Fernandez, J., Fita, L., Fumiere, Q., Giorgi, F., Goergen, K., Güttler, I., Halenka, T., Heinzeller, D., Hodnebrog, Ø., Jacob, D., Kartsios, S., Katragkou, E., Kendon, E., Khodayar, S., Kunstmann, H., Knist, S., Lavín-Gullón, A., Lind, P., Lorenz, T., Maraun, D., Marelle, L., van Meijgaard, E., Milovac, J., Myhre, G., Panitz, H.-J., Piazza, M., Raffa, M., Raub, T., Rockel, B., Schär, C., Sieck, K., Soares, P. M. M., Somot, S., Srnec, L., Stocchi, P., Tölle, M. H., Truhetz, H., Vautard, R., de Vries, H., and Warrach-Sagi, K.: A first-of-its-kind multi-model convection permitting ensemble for investigating convective phenomena over Europe and the Mediterranean, Clim. Dynam., 55, 3-34, https://doi.org/10.1007/s00382-018-4521-8, 2020.

Das, S., Narula, P., and Sarkar, K.: Design of intermittent rainfall-pattern for structures with gridded data: Validation and implementation, J. Build. Eng., 27, 100939, https://doi.org/10.1016/j.jobe.2019.100939, 2020.

Delage, Y.: Parameterising sub-grid scale vertical transport in atmospheric models under statically stable conditions, Bound.-Layer Meteorol., 82, 1, 23-48, https://doi.org/10.1023/A:1000132524077, 1997.

Delage, Y. and Girard, C.: Stability functions correct at the free convection limit and consistent for both the surface and Ekman layers, Bound.-Layer Meteorol., 58, 19-31, https://doi.org/10.1007/BF00120749, 1992.

Delicado, P. and Goria, M. N.: A small sample comparison of maximum likelihood, moments and L-moments methods for the asymmetric exponential power distribution. Comput. Stat. Data Anal., 52, 1661-1673, https://doi.org/10.1016/j.csda.2007.05.021, 2008.

de Michele, C., Rosso, R., and Rulli, M. C.: Il regime delle precipitazioni intense sul territorio della Lombardia. ARPA Lombardia, 2005.

Deser, C., Phillips, A., Bourdette, V., and Teng, H.: Uncertainty in climate change projections: the role of internal variability, Clim. Dynam., 38, 527-546, https://doi.org/10.1007/s00382010-0977-x, 2012.

DWD (Deutscher Wetterdienst): KOSTRA_DWD_2010R, https://opendata.dwd.de/climate_environment/CDC/grids_ germany/return_periods/precipitation/KOSTRA/KOSTRA_ DWD_2010R/asc/, last access: 21 October 2019. 
Dyrrdal, A. V., Lenkoski, A., Thorarinsdottir, T. L., and Stordal, F.: Bayesian hierarchical modeling of extreme hourly precipitation in Norway. Environmetrics, 26, 89-106, https://doi.org/10.1002/env.2301, 2015.

EEA (European Environment Agency): Economic losses from climate-related extremes in Europe, Tech. Rep., Copenhagen, Denmark, 28, 2019.

Førland, E. J., Allerup, P., Dahlström, B., Elomaa, E., Jónsson, T., Madsen, H., Perälä, J., Rissanen, P., Vedin, H., and Vejen, F.: Manual for operational correction of nordic precipitation data, Tech. Rep., Norwegian Meteorological Institute, Oslo, Norway, 1996.

Forzieri, G., Bianchi, A., Batista e Silva, F., Herrera, M. A. M., Leblois, A., Lavalle, C., Aerts, J. C. J. H., and Feyen, L.: Escalating impacts of climate extremes on critical infrastructures in Europe, Glob. Env. Change, 48, 97-107, https://doi.org/10.1016/j.gloenvcha.2017.11.007, 2018.

Fyfe, J. C., Derksen, C., Mudryk, L., Flato, G. M., Santer, B. D., Swart, N. C., Molotch, N. P., Zhang, X., Wan, H., Arora, V. K., Scinocca, J., and Jiao, Y.: Large near-term projected snowpack loss over the western United States, Nat. Commun., 8, 14996, https://doi.org/10.1038/ncomms14996, 2017.

Gill, J. C. and Malamud, B. D.: Reviewing and visualizing the interactions of natural hazards, Rev. Geophys., 52, 680-722, https://doi.org/10.1002/2013RG000445, 2014.

Gilleland, E. and Katz, R. W.: extRemes 2.0: An Extreme Value Analysis Package in R, J. Stat. Softw., 72, 8, https://doi.org/10.18637/jss.v072.i08, 2016.

Groenemeijer, P., Becker, N., Djidara, M., Gavin, K., Hellenberg, T., Holzer, A. M., Juga, I., Jokinen, P., Jylhä, K., Lehtonen, I., Mäkelä, H., Morales Napoles, O., Nissen, K. M., Paprotny, D., Prak, P., Púčik, T., Tijssen, L., and Vajda, A.: Past cases of extreme weather impact on critical infrastructure in Europe, Tech. Rep., Wesssling, Germany, 130, 2015.

Hawkins, E. and Sutton, R.: The potential to narrow uncertainty in regional climate predictions, Bull. Am. Meteorol. Soc., 90, 1095-1108, https://doi.org/10.1175/2009BAMS2607.1, 2009.

Hennemuth, B., Bender, S., Buelow, K., Dreier, N., Keup-Thiel, E., Krueger, O., Muddersbach, C., Radermacher, D., and Schoetter, R.: Statistical methods for the analysis of simulated and observed climate data, applied in projects and institutions dealing with climate change impact and adaptation, CSC Report 13, Climate Service Center, Germany, 2013.

Hernández-Díaz L., Laprise, R., Sushama, L., Martynov, A., Winger, K., and Dugas, B.: Climate simulation over the CORDEX-Africa domain using the fifth-generation Canadian Regional Climate Model (CRCM5), Clim Dynam., 40, 14151433, https://doi.org/10.1007/s00382-012-1387-z, 2012.

Herrera, S., Gutiérrez, J. M., Ancell, R., Pons, M. R., Frias, M. D., and Fernandez, J.: Development and analysis of a 50 year high-resolution daily gridded precipitation dataset over Spain (Spain02), Int. J. Climatol., 32, 74-85, https://doi.org/10.1002/joc.2256, 2012.

Hofstra, N., Haylock, M., New, M., Jones, P., and Frei, C.: Comparison of six methods for the interpolation of daily, European climate data, J. Geophys. Res., 113, D21110, https://doi.org/10.1029/2008JD010100, 2008.

Hosking, J. R. M., Wallis, J. R., and Wood, E. F.: Estimation of the Generalized Extreme-Value Distribution by the Method of Probability-Weighted Moments, Technometrics, 27, 251-261, https://doi.org/10.1080/00401706.1985.10488049, 1985.

Hu, Q., Li, Z., Wang, L., Huang, Y., Wang, Y., and Li, L.: Rainfall Spatial Estimations: A Review from Spatial Interpolation to Multi-Source Data Merging, Water, 11, 579, https://doi.org/10.3390/w11030579, 2019.

IPMA (Instituto Português do Mar e da Atmosfera): Daily gridded precipitation dataset over mainland Portugal, https://www.ipma. $\mathrm{pt} / \mathrm{en} /$ produtoseservicos/index.jsp? page=dataset.pt02.xml, last access: 12 October 2019.

Isotta, F. A., Frei, C., Weilguni, V., Tadić, M. P., Lassègues, P., Rudolf, B., Pavan, V., Cacciamani, C., Antolini, G., Ratto, S. M., Munari, M., Micheletti, S., Bonati, V., Lussana, C., Ronchi, C., Panettieri, E., Marigo, G., and Vertačnik, G.: The climate of daily precipitation in the Alps: development and analysis of a highresolution grid dataset from pan-Alpine rain-gauge data, Int. J. Climatol., 34, 1657-1675, https://doi.org/10.1002/joc.3794, 2014.

Junghänel, T., Ertel, H., and Deutschländer, T.: Bericht zur Revision der koordinierten Starkregenregionalisierung und -auswertung des Deutschen Wetterdienstes in der Version 2010, Tech. Rep., Deutscher Wetterdienst, Offenbach a. M., Germany, 30, 2017.

Kain, J. S. and Fritsch, J. M.: A one-dimensional entraining/detraining plume model and its application in convective parameterization, J. Atmos. Sci., 47, 2784-2802, https://doi.org/10.1175/15200469(1990)047<2784:AODEPM>2.0.CO;2, 1990.

Kainz, H., Beutle, K., Ertl, T., Fenz, R., Flamisch, N., Fritsch, E., Fuchsluger, H., Gruber, G., Hackspiel, A., Hohenauer, R., Klager, F., Lesky, U., Nechansky, N., Nipitsch, M., Pfannhauser, G., Posch, A., Rauch, W., Schaar, W., Schranz, J., Sprung, W., Telegdy, T., and Lehner, F.: Niederschlagsdaten zur Anwendung der ÖWAV-Regelblätter 11 und 19, Tech. Rep., ÖWAV, 2007.

Kendon, E. J., Roberts, N. M., Fowler, H. J., Roberts, M. J., Chan, S. C., and Senior, C. A.: Heavier summer downpours with climate change revealed by weather forecast resolution model, Nat. Clim. Change, 4, 570-576, 2014.

Kendon, E. J., Ban, N., Roberts, N. M., Fowler, H. J., Roberts, M. J., Chan, S. C., Evans, J. P., Fosser, G., and Wilkinson, J. M.: Do Convection-Permitting Regional Climate Models Improve Projections of Future Precipitation Change?, Bull. Am. Meteorol. Soc., 98, 79-93, https://doi.org/10.1175/BAMS-D-150004.1, 2017.

Kharin, V. and Zwiers, F.: Changes in the extremes in an ensemble of transient climate simulations with a coupled atmosphere-ocean GCM. J. Climate, 13, 3760-3788, https://doi.org/10.1175/15200442(2000)013<3760:CITEIA>2.0.CO;2, 2000.

KNMI (Koninklijk Nederlands Meteorologisch Instituut): precipitation - daily precipitation sum in the Netherlands, https://data. knmi.nl/datasets/Rd1/5, last access: 2 October 2019.

Kotlarski, S., Keuler, K., Christensen, O. B., Colette, A., Déqué, M., Gobiet, A., Goergen, K., Jacob, D., Lüthi, D., van Meijgaard, E., Nikulin, G., Schär, C., Teichmann, C., Vautard, R., Warrach-Sagi, K., and Wulfmeyer, V.: Regional climate modeling on European scales: a joint standard evaluation of the EUROCORDEX RCM ensemble, Geosci. Model Dev., 7, 1297-1333, https://doi.org/10.5194/gmd-7-1297-2014, 2014. 
Krøgli, I. K., Devoli, G., Colleuille, H., Boje, S., Sund, M., and Engen, I. K.: The Norwegian forecasting and warning service for rainfall- and snowmelt-induced landslides, Nat. Hazards Earth Syst. Sci., 18, 1427-1450, https://doi.org/10.5194/nhess18-1427-2018, 2018.

Kuo, H.-L.: On formation and intensification of tropical cyclones through latent heat release by cumulus convection, J. Atmos. Sci., 22, 1, 40-63, https://doi.org/10.1175/15200469(1965)022<0040:OFAIOT>2.0.CO;2, 1965.

Lazoglou, G. and Anagnostopoulou, C.: An Overview of Statistical Methods for Studying the Extreme Rainfalls in Mediterranean, Proceedings, 1, 681; https://doi.org/10.3390/ecas201704132, 2017.

Leduc, M., Mailhot, A., Frigon, A., Martel, J. L., Ludwig, R., Brietzke, G. B., Giguère, M., Brissette, F., Turcotte, R., Braun, M., and Scinocca, J.: The ClimEx project: a 50-member ensemble of climate change projections at $12-\mathrm{km}$ resolution over Europe and northeastern north America with the Canadian regional climate model (CRCM5), J. Appl. Meteorol. Climatol., 58, 663693, https://doi.org/10.1175/JAMC-D-18-0021.1, 2019.

Lenderink G. and van Meijgaard E.: Increase in hourly precipitation extremes beyond expectations from temperature changes, Nat. Geosci., 1, 511-514, https://doi.org/10.1038/ngeo262, 2008.

Lewis, E., Fowler, H., Alexander, L., Dunn, R., McClean, F., Barbero, R., Guerreiro, S., Li, X.-F., and Blenkinsop, S.: GSDR: A Global Sub-Daily Rainfall Dataset, J. Clim., 32, 4715-4729, https://doi.org/10.1175/JCLI-D-18-0143.1, 2019a.

Lewis, E., Quinn, N., Blenkinsop, S., Fowler, H. J., Freer, J., Tanguy, M., Hitt, O., Coxon, G., Bates, P., and Woods, R.: Gridded estimates of hourly areal rainfall for Great Britain (1990-2014) [CEH-GEAR1hr], NERC Environmental Information Data Centre, https://doi.org/10.5285/d4ddc781-25f3-423abba0-747cc82dc6fa, 2019b.

Libertino, A., Ganora, D., and Claps, P.: Technical note: Spacetime analysis of rainfall extremes in Italy: clues from a reconciled dataset, Hydrol. Earth Syst. Sci., 22, 2705-2715, https://doi.org/10.5194/hess-22-2705-2018, 2018.

Lussana, C. and Tveito, O. E.: senorge2, https://doi.org/10.5281/zenodo.845733, 2017.

Lussana, C., Saloranta, T., Skaugen, T., Magnusson, J., Tveito, O. E., and Andersen, J.: seNorge2 daily precipitation, an observational gridded dataset over Norway from 1957 to the present day, Earth Syst. Sci. Data, 10, 235-249, https://doi.org/10.5194/essd10-235-2018, 2018.

Madsen, H., Gregersen, I. B., Rosbjerg, D., and Arnbjerg-Nielsen, K.: Regional frequency analysis of short duration rainfall extremes using gridded daily rainfall data as co-variate, Water Sci. Technol., 75, 1971-1981, https://doi.org/10.2166/wst.2017.089, 2017.

Mäkinen, H., Kaseva, J., Balek, J., Kersebaum, K., Nendel, C., Gobin, A., Olesen, J., Bindi, M., Ferrise, R., Moriondo, M., Rodríguez, A., Ruiz-Ramos, M., Takáč, J., Bezák, P., Ventrella, D., Ruget, F., Capellades, G., and Kahiluoto, H.: Sensitivity of European wheat to extreme weather, Field Crop. Res., 222, 209-217, https://doi.org/10.1016/j.fcr.2017.11.008, 2018.

Malitz, G. and Ertel, H.: KOSTRA-DWD2010: Starkniederschlagshöhen für Deutschland (Bezugszeitraum 1951 bis 2010), Tech. Rep., Deutscher Wetterdienst, Offenbach a. M., Germany, 40, 2015.
Manfreda, S., Sole, A., and De Costanzo, G.: Le precipitazioni estreme in Basilicata, Editrice Universo sud Società Cooperativa, Potenza, Italy, 148, 2015.

Marchi, L., Borga, M., Preciso, E., and Gaume, E.: Characterisation of selected extreme flash floods in Europe and implications for flood risk management, J. Hydrol., 394, 118-133, https://doi.org/10.1016/j.jhydrol.2010.07.017, 2010.

Martynov, A., Sushama, L., Laprise, R., Winger, K., and Dugas, B.: Interactive lakes in the Canadian Regional Climate Model, version 5: the role of lakes in the regional climate of North America, Tellus A, 64, 16226, https://doi.org/10.3402/tellusa.v64i0.16226, 2012.

Martynov, A., Laprise, R., Sushama, L., Winger, K., Šeparović, L., and Dugas, B.: Reanalysis-driven climate simulation over CORDEX North America domain using the Canadian Regional Climate Model, version 5: model performance evaluation, Clim. Dynam., 41, 2973-3005, https://doi.org/10.1007/s00382013-1778-9, 2013.

McFarlane, N.: The effect of orographically excited gravity wave drag on the general circulation of the lower stratosphere and troposphere. J. Atmos. Sci., 44, 14, 1775-1800, https://doi.org/10.1175/15200469(1987)044<1775:TEOOEG>2.0.CO;2, 1987.

McTaggart-Cowan, R. and Zadra, A.: Representing Richardson number hysteresis in the NWP boundary layer, Mon. Weather Rev., 143, 1232-1258, https://doi.org/10.1175/MWRD-14-00179.1, 2015.

MeteoSwiss: Standard period 1966-2015, https://www. meteoswiss.admin.ch/home/climate/swiss-climate-in-detail/ extreme-value-analyses/standard-period.html?station=int (last access: 11 October 2019), 12 May 2016.

Meteotrentino: Stazioni Meteorologiche, http://storico. meteotrentino.it/web.htm, last access: 21 December 2019.

Mineo, C., Ridolfi, E., Napolitano, F., and Russo, F.: The Areal Reduction Factor: A New Analytical Expression For The Lazio Region In Central Italy, J. Hydrol., 560, 471-479, https://doi.org/10.1016/j.jhydrol.2018.03.033, 2018.

Morbidelli, R., Saltalippi, C., Cifrodelli, M., Flammini, A., Corradini, C., Brocca, L., and Stelluti, M.: Analisi delle precipitazioni intense in Umbria, Perugia, Italy, 472, 2016.

Muller, A., Arnaud, P., Lang, M., and Lavabre, J.: Uncertainties of extreme rainfall quantiles estimated by a stochastic rainfall model and by a generalized Pareto distribution/Incertitudes des quantiles extrêmes de pluie estimés par un modèle stochastique d'averses et par une loi de Pareto généralisée, Hydrol. Sci. J., 54, 417-429, https://doi.org/10.1623/hysj.54.3.417, 2009.

Nissen, K. M. and Ulbrich, U.: Increasing frequencies and changing characteristics of heavy precipitation events threatening infrastructure in Europe under climate change, Nat. Hazards Earth Syst. Sci., 17, 1177-1190, https://doi.org/10.5194/nhess17-1177-2017, 2017.

Ochoa-Rodriguez, S., Wang, L.-P., Gires, A., Pina, R. D., ReinosoRondinel, R., Bruni, G., Ichiba, A., Gaitan, S., Cristiano, E., van Assel, J., Kroll, S., Murlà-Tuyls, D., Tisserand, B., Schertzer, D., Tchiguirinskaia, I., Onof, C., Willems, P., and ten Veldhuis, M.-C.: Impact of spatial and temporal resolution of rainfall inputs on urban hydrodynamic modelling outputs: A multi-catchment investigation, J. Hydrol., 531, 389-407, https://doi.org/10.1016/j.jhydrol.2015.05.035, 2015. 
Olsson, J., Berg, P., Eronn, A., Simonsson, L., Södling, J., Wern, L., and Yang, W.: Extremregn i nuvarande och framtida klimat: analyser av observationer och framtidsscenarier, Klimatologi SMHI, 47, 83, 2018.

Panagos, P., Ballabio, C., Meusburger, K., Spinoni, J., Alewell, C., and Borrelli, P.: Towards estimates of future rainfall erosivity in Europe based on REDES and WorldClim datasets, J. Hydrol., 548, 251-262, https://doi.org/10.1016/j.hydrol.2017.03.006, 2017.

PCRM (Protezione Civile Regionale Marche): Regional Meteorological-Hydrological Information System, http: //app.protezionecivile.marche.it/sol/indexjs.sol?lang=en\&Ok=1, last access: 20 December 2019.

Petrucci, O., Aceto, L., Bianchi, C., Bigot, V., Brázdil, R., Pereira, S., Kahraman, A., Kılıç, Ö., Kotroni, V., Llasat, M. C., LlasatBotija, M., Papagiannaki, K., Pasqua, A. A., Řehoř, J., Rossello Geli, J., Salvati, P., Vinet, F., and Zêzere, J. L.: Flood Fatalities in Europe, 1980-2018: Variability, Features, and Lessons to Learn, Water, 11, 1682, https://doi.org/10.3390/w11081682, 2019.

Poschlod, B.: 10 year return levels of precipitation over Europe based on the CRCM5-LE, https://doi.org/10.5281/zenodo.3878887, 2020.

Poschlod, B., Hodnebrog, Ø., Wood, R. R., Alterskjær, K., Ludwig, R., Myhre, G., and Sillmann, J.: Comparison and evaluation of statistical rainfall disaggregation and high-resolution dynamical downscaling over complex terrain, J. Hydrometeorol., 19, 19731982, https://doi.org/10.1175/JHM-D-18-0132.1, 2018.

Poschlod, B., Zscheischler, J., Sillmann, J., Wood, R. R., and Ludwig, R.: Climate change effects on hydrometeorological compound events over southern Norway, Weather Clim. Extremes, 28, 100253, https://doi.org/10.1016/j.wace.2020.100253, 2020.

Prein, A. F., Langhans, W., Fosser, G., Ferrone, A., Ban, N., Goergen, K., Keller, M., Tölle, M., Gutjahr, O., Feser, F., Brisson, E., Kollet, S., Schmidli, J., van Lipzig, N. P. M., and Leung, R.: A review on regional convection-permitting climate modeling: Demonstrations, prospects, and challenges, Rev. Geophys., 53, 323-361, https://doi.org/10.1002/2014RG000475, 2015.

Richter, D.: Ergebnisse methodischer Untersuchungen zur Korrektur des systematischen Meßfehlers des HellmannNiederschlagsmessers, Tech. Rep., Deutscher Wetterdienst, Offenbach a. M., Germany, 1995.

RM (Regione Molise): Studio del rischio idrogeologico nella regione. Analisi idrologica B.1.2, 65, 2001.

RMI (Royal Meteorological Institute): Le climat dans votre commune, https://www.meteo.be/fr/climat/atlas-climatique/ climat-dans-votre-commune, last access: 1 October 2019.

Rojas, R., Feyen, L., and Watkiss, P.: Climate change and river floods in the European Union: Socio-economic consequences and the costs and benefits of adaptation, Glob. Env. Change, 23, 1737-1751, https://doi.org/10.1016/j.gloenvcha.2013.08.006, 2013.

RT (Regione Toscana): SIR DATI/Archivio storico, http://www.sir. toscana.it/consistenza-rete, last access: 11 December 2019.

Santos, E. B., Lucio, P. S., and Santos e Silva, C. M.: Estimating return periods for daily precipitation extreme events over the Brazilian Amazon, Theor. Appl. Climatol., 126, 585-595, https://doi.org/10.1007/s00704-015-1605-9, 2016.

SEA (Slovenian Environment Agency): Povratne dobe za ekstremne padavine (novejša različica), http://meteo.arso.gov.si/ met/sl/climate/tables/precip_return_periods_newer/, last access: 30 January 2020.

SMG (Santander Meteorology Group): Dataset: Spain02 v5.0 0.11, https://meteo.unican.es/tds5/catalog/pr_Spain02_v5.0_011rot/ catalog.html?dataset=pr_Spain02_v5.0_011rot/Spain02_v5.0_ DD_011rot_aa3d_pr.nc, last access: 11 November 2019.

Sundquist, H.: A parameterization scheme for nonconvective condensation including prediction of cloud water content, Q. J. R. Meteorol. Soc., 104, 677-690, https://doi.org/10.1002/qj.49710444110, 1978.

Sundqvist, H., Berge, E., and Kristjansson, J. E.: Condensation and cloud parameterization studies with a mesoscale numerical weather prediction model, Mon. Weather Rev., 117, 1641-1657, 1989.

Sunyer, M. A., Luchner, J., Onof, C., Madsen, H., and ArnbjergNielsen, K.: Assessing the importance of spatio-temporal RCM resolution when estimating sub-daily extreme precipitation under current and future climate conditions, Int. J. Climatol., 37, 688705, https://doi.org/10.1002/joc.4733, 2016.

Swart, N. C., Cole, J. N. S., Kharin, V. V., Lazare, M., Scinocca, J. F., Gillett, N. P., Anstey, J., Arora, V., Christian, J. R., Hanna, S., Jiao, Y., Lee, W. G., Majaess, F., Saenko, O. A., Seiler, C., Seinen, C., Shao, A., Sigmond, M., Solheim, L., von Salzen, K., Yang, D., and Winter, B.: The Canadian Earth System Model version 5 (CanESM5.0.3), Geosci. Model Dev., 12, 4823-4873, https://doi.org/10.5194/gmd-12-4823-2019, 2019.

Tabari, H., De Troch, R., Giot, O., Hamdi, R., Termonia, P., Saeed, S., Brisson, E., Van Lipzig, N., and Willems, P.: Local impact analysis of climate change on precipitation extremes: are high-resolution climate models needed for realistic simulations?, Hydrol. Earth Syst. Sci., 20, 3843-3857, https://doi.org/10.5194/hess-20-3843-2016, 2016.

Trenberth, K. E., Zhang, Y., and Gehne, M.: Intermittency in precipitation: Duration, frequency, intensity, and amounts using hourly data, J. Hydrometeor., 18, 1393-1412, https://doi.org/10.1175/JHM-D-16-0263.1, 2017.

Venäläinen, A., Saku, S., Kilpeläinen, T., Jylhä, K., Tuomenvirta, H., Vajda, A., Räisänen, J., and Ruosteenoja, K.: Sään ääriilmiöistä Suomessa. (Aspects about climate extremes in Finland. Abstract in English.), Ilmatieteen laitos, Helsinki, Finland, 82, 2007.

Ventura, V., Paciorek, C. J., and Risbey, J. S.: Controlling the proportion of falsely rejected hypotheses when conducting multiple tests with climatological data, J. Clim., 17, 4343-4356, https://doi.org/10.1175/3199.1, 2004.

Verseghy, D. L.: CLASS - a Canadian land surface scheme for GCMS. I. Soil model, Int. J. Climatol. 11, 111-133, https://doi.org/10.1002/joc.3370110202, 1991.

Verseghy, D. L.: CLASS - the Canadian Land Surface Scheme (Version 3.4) - Technical Documentation (Version 1.1), Tech. Rep., Climate Research Division, Science and Technology Branch, Environment Canada, Toronto, Ontario, Canada, 183, 2009.

von Trentini, F., Leduc, M., and Ludwig, R.: Assessing natural variability in RCM signals: comparison of a multi model EURO-CORDEX ensemble with a 50-member single model large ensemble, Clim. Dynam., 53, 1963-1979, https://doi.org/10.1007/s00382-019-04755-8, 2019.

Westra, S., Fowler, H. J., Evans, J. P., Alexander, L. V., Berg, P., Johnson, F., Kendon, E. J., Lenderink, G., and Roberts, 
N. M.: Future changes to the intensity and frequency of short-duration extreme rainfall, Rev. Geophys., 52, 522-555, https://doi.org/10.1002/2014RG000464, 2014.

Wilks, D. S.: "The stippling shows statistically significant grid points": How research results are routinely overstated and overinterpreted, and what to do about it, Bull. Am. Meteorol. Soc., 97, 2263-2273, https://doi.org/10.1175/BAMS-D-15$00267.1,2016$.

Wilson, E. M.: Engineering Hydrology, Macmillan Education UK, London, 1-49, https://doi.org/10.1007/978-1-349-115228_1, 1990.

van de Vyver, H.: Spatial regression models for extreme precipitation in Belgium, Water Resour. Res., 48, W09549, https://doi.org/10.1029/2011WR011707, 2012. van den Hurk, B., van Meijgaard, E., de Valk, P., van Heeringen, K. J., and Gooijer, J.: Analysis of a compounding surge and precipitation event in The Netherlands, Environ. Res. Lett., 10, 035001, https://doi.org/10.1088/1748-9326/10/3/035001, 2015.

Zadra, A., Roch, M., Laroche, S., and Charron, M.: The subgridscale orographic blocking parametrization of the GEM Model, Atmos. Ocean, 41, 155-170, https://doi.org/10.3137/ao.410204, 2003.

Zolina, O., Simmer, C., Kapala, A., Shabanov, P., Becker, P., Mächel, H., Gulev, S., and Groisman, P.: Precipitation Variability and Extremes in Central Europe: New View from STAMMEX Results, Bull. Am. Meteorol. Soc., 95, 995-1002, https://doi.org/10.1175/BAMS-D-12-00134.1, 2014 